\title{
THE TUNTIAN SYSTEM IN XINJIANG UNDER THE QING DYNASTY: A PERSPECTIVE FROM ENVIRONMENTAL HISTORY ${ }^{1}$
}

\author{
TS'UI-JUNG LIU \\ Institute of Taiwan History, Academia Sinica \\ I-CHUN FAN \\ Institute of History and Philology, Academia Sinica
}

\section{Abstract}

The aim of this paper is not to reinvestigate the Tuntian system (屯田制度, the system of land tilled by colonists), but rather to explore its significance as it developed in Xinjiang during the Qing Dynasty (1644-1911) from the perspective of environmental history. This paper consists of four sections. First, it applies a Geographical Information System (GIS) technique to demonstrate spatial and temporal changes brought about by the Tuntian system in Xinjiang, based on available studies. Second, it analyses this land system from the viewpoint of property rights. Third, it discusses the landscape as shaped by colonists of various statuses, and finally, it traces the environmental changes in Xinjiang through the observations of Lin Zexu in 1842 and Xie Bin in 1917.

Key words: Tuntian System, Xinjiang, property right, landscape, environmental changes

\section{Introduction}

The Tuntian system (屯田制度， the system of land tilled by colonists) in China was first set up in the Western Han Dynasty (206 BC - AD 8); its nature and scale varied in later periods. It is not necessary to trace all studies here; however, it should be noted that more than 20 years ago, Lanzhou University gathered

1 The Chinese version of this article is included in Chen Yung-fa 陳永發, ed., Ming Qing diguo jiqi jinxiandai zhuangxing 明淸帝國及其近現代轉型 [The Ming-Qing Empire and its Modern Transformation] (Taipei: Yunchen wenhua, 2011), 203-65. This English version incorporates some revisions. 
many scholars to research this system and published a series of studies. ${ }^{2}$ This collective effort undoubtedly provided novel comprehensive knowledge regarding the Tuntian system in north-west China. Moreover, in recent years there have been at least three books on this subject. One focuses on the relationship between the land tilled by colonists and agricultural development in Xinjiang. ${ }^{3}$ The other two provide important findings regarding environmental changes in the region. ${ }^{4}$ The only deficiency of these books is that they do not have maps for helping readers to conceive the spatial distribution of land tilled by colonists.

The aim of this paper is not to reinvestigate the Tuntian system in Xinjiang during the Qing Dynasty (1644-1911), but rather to explore the significance of this land system, making use of previous studies, from the perspective of environmental history; in other words, the emphasis is on understanding the interaction between the Tuntian and the environment. Wang Xilong's book is the major reference of this paper and we acknowledge our thanks to him here.

This article first presents the distribution of the Tuntian established in Xinjiang, based on the materials assembled by Wang Xilong, and applies a Geographical Information System (GIS) technique to illustrate the spatial and temporal dimensions of this system. The second section will analyse this land system from the viewpoint of property rights. The third section will discuss the landscape shaped by the colonists' activities. Finally, the fourth section will try to trace environmental changes from observations by Lin Zexu 林則徐 (1785-1850) in 1842 and Xie Bin謝涁 (1887-1948) in 1917.

\section{The Tuntian system developed in Xinjiang}

This section will discuss briefly the Tuntian system as it developed in Xinjiang and present some maps to illustrate its changing overall spatial and temporal distribution (Maps 1-5) and the situations at different localities (Maps 6-11). These maps use the administrative divisions of 1820 as a basis and the digital system of “Chinese Civilization in Time and Space’ (中華文明之時空基礎架構)

2 Liu Guanghua 劉光華, Handai xibei tuntian yanjiu 漢代西北屯田研究 [Study on the Land tilled by Colonists in Northwest China in the Han Dynasty] (Lanzhou: Lanzhou University Press, 1988). Wang Xilong 王 希隆, Qingdai xibei tuntian yanjiu 清代西北屯田研究 [Study on the Land tilled by Colonists in Northwest China in the Qing Dynasty] (Lanzhou: Lanzhou University Press, 1990). Zhao Lisheng 趙麗生, ed., Gudai xibei tuntian kaifashi 古代西北屯田開發史 [History of Exploiting the Land tilled by Colonists in Northwest in Ancient China] (Lanzhou: Gansu Culture Press, 1997). Some findings of the first two books are also included in the third one.

3 Hua Li 華立, Qingdai Xinjiang nongyeh kaifashi 清代新疆農業開發史 [History of Agricultural Exploitation in Xinjiang during the Qing Dynasty] (Haerbin: Heilongjiang Education Press, 1998).

4 Huang Shengzhang 黃盛璋, ed., Lüzhou yanjiu 綠洲研究 [The Oasis Study] (Beijing: The Science Press, 2003); Zhao Zhen 趙珍, Qingdai xibei shengtai bianqian yanjiu 淸代西北生態變遷硏究 [Study on Northwest Ecological Changes in the Qing Dynasty] (Beijing: The People's Press, 2005). 
created by the GIS team of Academia Sinica, based on The Chinese Historical Atlas (中國歷史地圖集) edited by Tan Qixiang 譚其驤. ${ }^{5}$ Laid on top of each map is the NASA Landsat 7 satellite image. In addition, this section uses The Map of the Western Region made by Imperial Order (欽定皇輿西域圖志)and The Draft Local Gazette of Xinjiang (新疆師土志稿) to identify the distribution of the Tuntian. ${ }^{6}$

The Tuntian system that developed in north-west China during Qing Dynasty included five categories: Bingtun(兵屯, land tilled by soldiers), Qitun(旗屯, land tilled by soldiers of the Banners), Qiantun (遣屯, land tilled by exiled criminals), Mintun (民屯, land tilled by civilians), and Huitun (回屯, land tilled by the Uyghur 維吾爾人). Each category had different institutional arrangements. ${ }^{7}$ In the Qing period, there were 127,000 colonists in Xinjiang; of them 22,200 were soldiers of the Green Standard Army (綠營兵屯), 14,800 were soldiers of the Eight Banners (八旗兵屯), 37,500 were civilians, 4,300 were Uyghur, and 9,200 were exiled criminals. The total land area tilled by the colonists measured 3,020,000 mou (欯, 2,012.83 million $\mathrm{m}^{2}$ ), of which 64 per cent was in northern Xinjiang where the agricultural oases existing today were formed mostly during the Qing period. ${ }^{8}$ (See Map 1.)

The Bingtun system in north-west China was established in response to the war against the Dzungar (or Zhungar 準噶爾), who occupied Hami (哈密) in 1715. ${ }^{9}$ The Qing Government sent armies to fight against the Dzungar and set up Bingtun in western Mongolia, to the east of Jiayuguan (嘉峪關), and to the west of Turfan (吐魯番) for supplying military grain. ${ }^{10}$ From 1716, Bingtun were set up in Xinjiang consecutively at Balikun (巴里坤), Turfan and Hami. In the 1730s, Bingtun was interrupted when the Qing Government negotiated peace with the Dzungar. Later, the Qing Army entered Xinjiang to pacify rebellions and re-establish Bingtun. In 1757, three Bingtun of the Green Standard Army were established at the Gan (甘), Liang (涼) and Su (肅) garrisons. Until 1765, there were 18 Bingtun of various scales. ${ }^{11}$

\footnotetext{
5 This database, available at ccts.ascc.net/index.php?lang=zh-tw, was created by the GIS team of Academia Sinica under the leadership of I-chun Fan, co-author of this paper. We would like to thank Miss Pai Pi-ling 白璧玲 of the GIS team in helping to draw maps included in this paper. There is no conflict of property rights. 6 Fu Heng 傅恒 et al., comps, Qinting huangyu xiyu tuzhi 欽定皇輿西域圖志 [The Map of the Western Region made by Imperial Order] (Lanzhou: The Lanzhou Ancient Bookstore, 1990). Ma Dazheng 馬大正 and Hua Li 華立, eds, Xinjiang xiangtuzhi gao新疆㰾土志稿 [The Draft Local Gazette of Xinjiang] (Beijing: China National Microfilming Center for Library Resources, 1990).

7 Wang, Qingdai xibei tuntian yanjiu, 9.

8 Huang, Lüzhou yanjiu, 30.

9 Peter C. Perdue, China Marches West: The Qing Conquest of Central Eurasia (Cambridge, MA: Harvard University Press, 2005), chaps 5, 6, and 7 for details of conflict between the Qing and the Dzungar; chap. 9 for military colonies (based mostly on Wang Xilong's work).

10 Wang, Qingdai xibei tuntian yanjiu, 38-41, 44-45.

11 Wang, Qingdai xibei tuntian yanjiu, 47-51.
} 


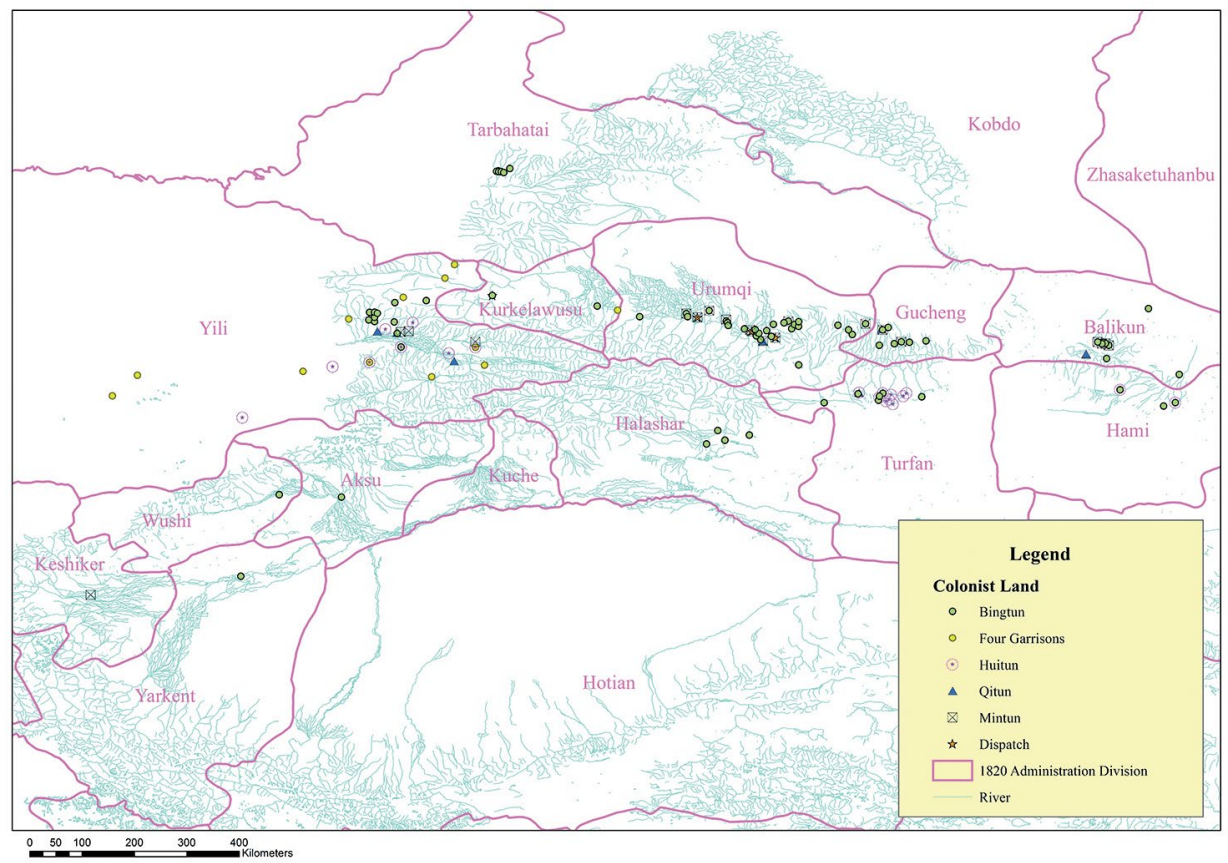

Map 1: The overall distribution of Tuntian in Qing Xinjiang.

The peak period of developing Bingtun in Xinjiang was from 1736 to 1820 . From 1821 onward, the Qing Government managed to develop agriculture in areas both to the north and to the south of the Tianshan (天山) Mountain; however, some Bingtun were withdrawn one after the other. In 1840, seven Bingtun at Turfan were withdrawn. In 1843, Bingtun at Altishahr (哈喇沙爾) and Wushi (烏什, i.e. Uchturpan) were also withdrawn. In 1853, the soldiers at Yili (伊犁) were withdrawn and 210 soldiers at Tarbahatai (塔爾巴哈台) were also removed. In 1863, Bingtun at the Middle, Left and Right garrisons of Urumqi (烏魯木齊), as well as those at Balikun, Mulei (木壘), Gucheng (古城), Kucha (庫車), and Jingho (精河), divided the land among soldiers, whose salaries were paid with agricultural produce.

The labour of Bingtun comprised two categories: 'shifting' or migrant soldiers (換班屯兵) and soldiers with families (攜春屯兵). In the beginning, the lands of Bingtun were cultivated mainly by migrant soldiers. In 1762, Balikun started to introduce soldiers with families, and then this practice was adopted at other localities. By 1850, there were more than 6,100 soldiers with families (71 per cent) and 2,517 migrant soldiers (29 per cent). ${ }^{12}$

12 Wang, Qingdai xibei tuntian yanjiu, 60-5. At Khobdo (科布多), the Bingtun had 100 migrant soldiers which are not included here as the locality is in Mongolia. 
After the Dzungar were pacified, the Qitun in Xinjiang was managed by garrisons of the Eight Banners. During the period 1764-74, the Qing Government dispatched 11,500 Manchu and Mongol Banner soldiers from Liangzhou (涼州), Zhuanglang (庄浪), Xi-an (西安), Ningxia (寧夏), and Rehe (熱河) to stations at Yili, Urumqi, Balikun, and Gucheng. In 1780, the Manchu garrison at Turfan was established and a section of Eight Banners soldiers was sent to Urumqi. As the population of Eight Banners garrisons in Xinjiang doubled from the 1790s to the first decade of the 1800s, the Qing Government adopted various strategies to solve the problem of their livelihood. One way was to establish Qitun. The proposal was made in 1764 but was not put into practice until the early 1800s. According to the Yili General Song Yun 松笉 (1752-1835), the delay was because Manchu Banners hesitated as they worried that military budgets might be cut once the Qitun land was cultivated. In 1802, Song Yun determined to solve the problem. He first asked the Manchu garrisons at Huiyuan (惠遠) and Huining (惠寧) to dispatch 360 soldiers for an experiment in cultivating the land. He personally conducted field investigations around the area, sent personnel to build hydraulic works to open a large canal along the north bank of Yili River, and to search for sources of spring water in the north-west part of Xinjiang, to build irrigation channels, and finally to obtain 120,000 mou of land for cultivation. ${ }^{13}$

In addition to soldiers of the Manchu and Mongol Eight Banners transferred from Shaanxi (陝西) and Gansu (甘肅), officers and soldiers of the Chahar (察哈爾), Xibe (錫伯), Solun (索倫) and Ulet (厄魯特) garrisons were also dispatched in 1764-65 from Zhangjiakou (張家口), Shengjing (盛京), Heilongjiang (黑龍江) and Rehe to establish Qitun at Yili. ${ }^{14}$

Qiantun in north-west China was founded in 1724. At that time, Nian Gengyao 年美堯 (1679-1726), the Frontier Pacifying General-in-Chief (撫遠將軍), dispatched criminals in the provinces of Zhili (直隸), Henan (河南), Shandong (山東), Shanxi (山西) and Shaanxi to till the land at Datonghe (大通河) and Bulongjier (布隆吉爾). The Qing Government agreed to dispatch criminals with their wives to Bulongjier to till the land and sow it with seed that was officially provided, and to pay taxes after three years. The main purpose of dispatching exiled criminals to till the land at Bulongjier was to supply grain for the garrisons. In 1758, the Censor Liu Tsongwei 劉宗魏 (Jinshi 進士 [imperial examination], 1748) proposed to dispatch exiled criminals to Xinjiang to supplement the Bingtun labour force. After his proposal was approved, the Board of Punishments drew up a regulation for dispatching criminals to Xinjiang. This regulation was amended several times in the reigns of Qianlong

13 Wang, Qingdai xibei tuntian yanjiu, 85-91.

14 Wang, Qingdai xibei tuntian yanjiu, 99-100. 
(1736-95), Jiaqing (1796-1820), Daoguang (1821-50), and Xianfeng (1851-74). However, the work continued without interruption. During the years 1862-77, when Xinjiang was disturbed by a Muslim revolt, criminals were dispatched to Heilongjiang, Yunnan (雲南), and Guizhou (貴州) instead. After recovering Xinjiang in 1877, the old practice of dispatching criminals was resumed. Throughout the Qing period, exiled criminals were dispatched to both northern and southern Xinjiang. The lands of Qiantun tilled by criminals were mostly located around the garrisons of the Green Standard Army. In addition to the Qiantun set up at Anxi (安西) in Gansu, nine were established in Xinjiang, of which four at Hami, Balikun, Urumqi, and Pizhan (辟展) were set up in 1761, three at Kurkelawusu (庫爾喀拉烏蘇), Jinghe, and Yili in 1766, one at Tarbahatai in 1775, and the other at Qarashar (喀刺沙爾) in 1796.

After arriving at Xinjiang, most exiled criminals were engaged in tilling Bingtun land. They were classified into one of two groups according to the degree of their crimes: to become slaves of soldiers, or to till a certain share of land; both groups were, however, under the control of soldiers. At Urumqi, Manas (瑪納斯), Jinghe, Kurkelawusu, and Tarbahatai, each exiled criminal was given 12 mou of land, and an additional 5 mou was given to each one who had a family. The Qing Government set up regulations for rewards and punishments for exiled criminals who cultivated a share of the land. It also gave three choices to the exiled criminals in Xinjiang when their terms of punishment ended: to become a soldier, to return home, or to settle down at the frontier. Most exiled criminals chose the last. Moreover, there were some exiled criminals who were not dispatched to military colonies but instead to civil colonies at places such as Urumqi; they were known as situated households (Anchahu 安插戶). Their origin, management, and treatment differed from those dispatched to military colonies. $^{15}$

In 1884, when Xinjiang Province was established, the Qing Government considered dispatching exiled criminals again. But the first Governor, Liu Jintang 劉錦棠 (1844-94), considered that the old practice was no longer suitable for the new situation. Therefore, he decided to have them placed by local officials by implementing the Regulation of Colonies in Xinjiang (新疆屯墾章程), also known as the Regulation of Civil Colonies (民屯章程). This regulation brought forth a great change in the nature of exile for criminals in Xinjiang - to dispatch them to civil colonies instead of military ones. ${ }^{16}$

Mintun began in Xinjiang after the pacification of the Dzungar. From 1761 the Qing Government started to set up Mintun in northern Xinjiang. The cultivators of Mintun consisted of two categories: those recruited from

15 Wang, Qingdai xibei tuntian yanjiu, 119-21.

16 Wang, Qingdai xibei tuntian yanjiu, 125-9, 139-48. 
the interior (內地招募) and those who came from the frontier voluntarily with an agreement (塞外認墾). The cultivators recruited from the interior were mainly jobless people and tenant farmers from the area of the West Corridor (Hexi 河西). The cultivators who came from the frontier voluntarily were mostly hired labourers and craftsmen living in northern Xinjiang. In 1762, the managerial official Jing-e-li 旌額理 (d. 1777) memorialised that the families of those who applied to cultivate frontier land would be sent there with official support. In 1772, the Shaan-Gan Governor-General Wen Shou 文綬 (d. 1784) suggested that the procedures for examining documents for passing through Jiayuguan should be simplified; he also used the official budget to repair the road leading to Urumqi. These favourable conditions attracted quite a number of civil households to go to cultivate the frontier land voluntarily. ${ }^{17}$

The distribution of Mintun in northern Xinjiang extended quite widely. From Balikun to Urumqi and Yili, wherever there were Bingtun there were Mintun. The peak period for the establishment of Mintun was 1736-1820. In 1789, at Balikun and Urumqi, the population of voluntary cultivators with agreements reached 120,537. In 1803, the number increased to more than 150,000; by counting those in Jinghe, Kurkelawusu, Yili, and Tarbahatai together, the total number of voluntary cultivators was 155,000. It can be estimated that there were 200,000 people by 1820 . As for the land area, by 1795 the total cultivated voluntarily at Balikun and Urumqi was 1,014,879 mou; at Tarbahatai it was 3,000 mou. By 1820, Yili had 60,193 mou under cultivation. Thus, it can be estimated that by 1820 the acreage of Mintun in northern Xinjiang was more than $1,080,000$ mou. ${ }^{18}$

In southern Xinjiang, Mintun started in the early 1820s. The region was an agricultural district with a long history. After the Dzungar were pacified in 1755, the emphasis was put on northern Xinjiang, and only a certain number of migrant soldiers were sent to southern Xinjiang. From about 1820, the leader of White Mountain faction, Jahangir Khoja 張格爾 (1788-1828), disturbed southern Xinjiang frequently. In 1826, he mobilised his people to attack and occupy the four cities Kashgar (喀什噶爾), Yengisar (英吉沙爾), Khotan (和闐), and Yarkent (葉爾姜). In 1828, Khoja was captured and sent to Beijing to face the death penalty. However, two years later, his elder brother, Yusuf Khass 玉素甫, attacked Kashgar and Yarkent. The turmoil in southern Xinjiang exhausted the energy of the Qing Army and the migrant garrison was not able to adapt to the situation. In 1827, the advisory official Wu Longa 武 隆阿 (d. 1831) proposed setting up garrison forces at four cities in southern Xinjiang and recruiting people from the interior to cultivate the land. In the

17 Wang, Qingdai xibei tuntian yanjiu, 149-51.

18 Wang, Qingdai xibei tuntian yanjiu, 173-7. 
same year, the Censor Qian Yiji錢儀吉 (1783-1850) also recommended imitating northern Xinjiang by setting up Mintun. In 1831, the Yili General Chang Ling 長齡 (1759-1839) further proposed measures for recruiting cultivators to till the land in the western part of southern Xinjiang. Thus, two localities with available land started to recruit cultivators: one was Kelaheyi (喀拉赫依) around Kashgar and the other was Barchuke (巴爾楚克) at Yarkent. ${ }^{19}$

After a decade of turmoil, Xinjiang Province was established in 1884 and the first Governor, Liu Jintang, considered that the most urgent task was to establish land for colonists and to recruit people to cultivate wastelands. Moreover, there were also some changes in the organisation of Mintun. According to the Regulation of Civil Colonies issued by Liu Jintang, the organisation of Mintun was similar to that of the Yingtian (營田, camping field system), in which one Tunzhang (屯長, head of colony) was appointed for every 10 households, one Tunzheng (屯正, principal of colony) for every 50 households, and one Weiyuan (委員, commissioner) to supervise every five Tunzheng. This system was much more rigorous than the old one, which was managed only by household heads. ${ }^{20}$

Huitun was the land tilled by the Uyghur who had settled in Xinjiang. Basically, the nature of Huitun was similar to that of Mintun. During the period when southern Xinjiang was occupied by the Dzungar, the Uyghur living at Hami and Turfan attached themselves to the Qing Government. After pacifying the Dzungar, the Qing Government moved the Uyghur from southern Xinjiang to cultivate the land along the Yili valley. ${ }^{21}$

Huitun at Yili had been maintained for more than a century. This was not only due to favourable agricultural conditions around Yili - the fertile land, abundant water resources and moderate climate - but also because the Uyghur had lived there before; they had fled to southern Xinjiang during the wars and they were willing to return to Yili. Moreover, although the tax rate was high, the farm animals were provided by officials and there was no other burden, and thus it was possible for them to have a more stable livelihood. ${ }^{22}$

The significance of Lin Zexu's investigation in southern Xinjiang should be noted here. He was dismissed to go to Yili in 1842 after the Opium War. In 1844, Lin Zexu completed the hydraulic work of conducting the water from the Hashi River (哈什河) into the Qiwusu (齊烏蘇) channel; this work was praised by the Yili General Buyantai 布彥泰 (1791-1880), who suggested to the throne that Lin Zexu be reappointed to a position. Thus, the Daoguang Emperor ordered Lin Zexu to take up the responsibility of investigating cultivable land in southern

19 Wang, Qingdai xibei tuntian yanjiu, 177-9.

20 Wang, Qingdai xibei tuntian yanjiu, 182-83.

21 Wang, Qingdai xibei tuntian yanjiu, 190-93, especially Table 3, 190.

22 Wang, Qingdai xibei tuntian yanjiu, 194. 
Xinjiang. In December 1844, he went south from Yili to Qarashar and met the managerial official Quan Qing 全慶 (1802-82) to carry out the mission, which lasted about a year and covered eight cities. The investigation included local hydraulic works and the measurement of cultivable land, which accounted for about 600,000 mou distributed among eight localities, of which six were: Kucha $(68,000 \mathrm{mou})$, Wushi $(103,000 \mathrm{mou})$, Khotan $(100,000 \mathrm{mou})$, Yarkent $(98,000 \mathrm{mou})$, Kashgar (83,000 mou), and Qarashahr (10,000 mou). The results demonstrated the great potential of agricultural development in southern Xinjiang. However, the Qing Government was not able to efficiently move the people from the interior; the only option was to recruit the Uyghur to cultivate 95 per cent of the land. Lin Zexu and Quan Qing relayed the local reality to the Qing Government and thus helped the development of Huitun in Xinjiang. ${ }^{23}$

These maps illustrate the temporal changes in the early stage (1716-21), middle stage (1756-78), and later stage (1802-84). (See Maps 2-4.) Map 5 shows the acreage of each category of land at various locations.

In the early stage, five Bingtun were established.

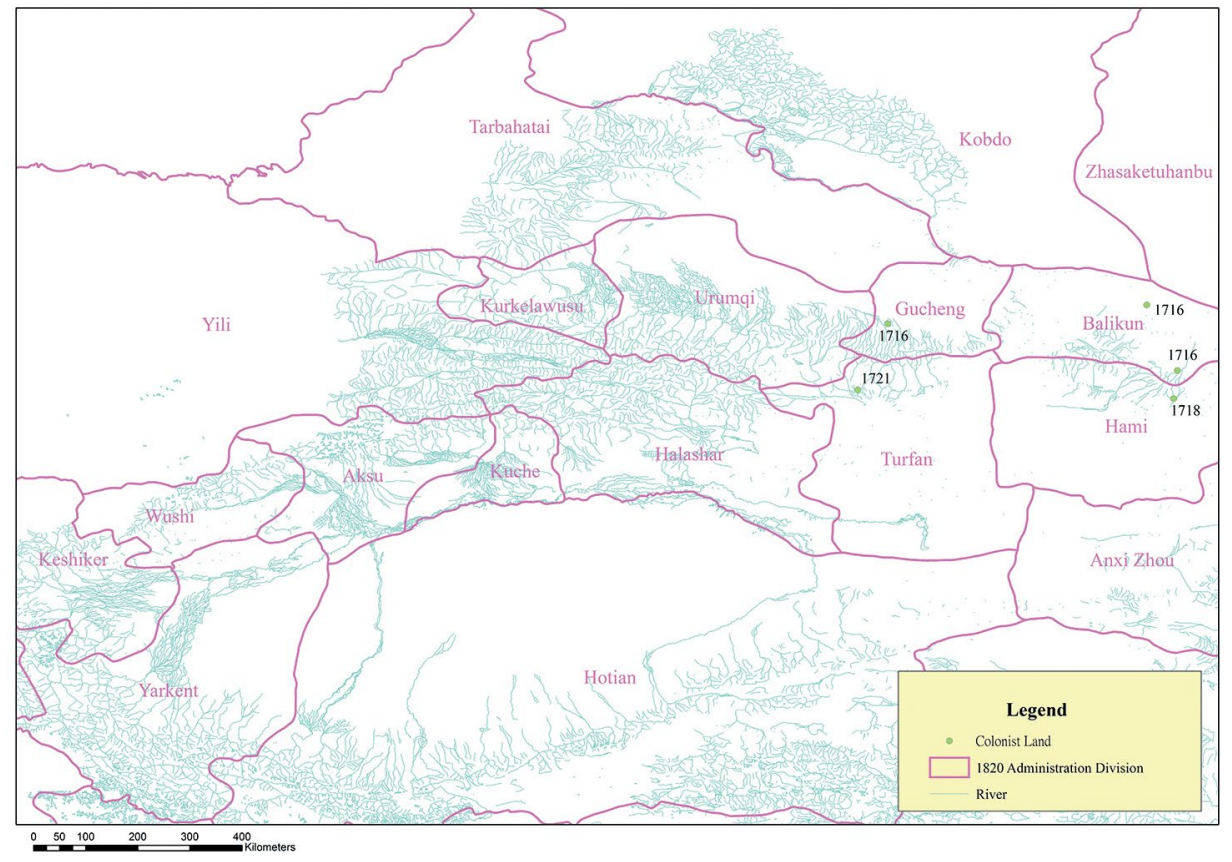

Map 2: The distribution of Tuntian in Xinjiang: The early stage (1716-21).

In the middle stage, 84 colonies of Bingtun, Qitun, Huitun, and Mintun.

23 Wang, Qingdai xibei tuntian yanjiu, 217-18. 


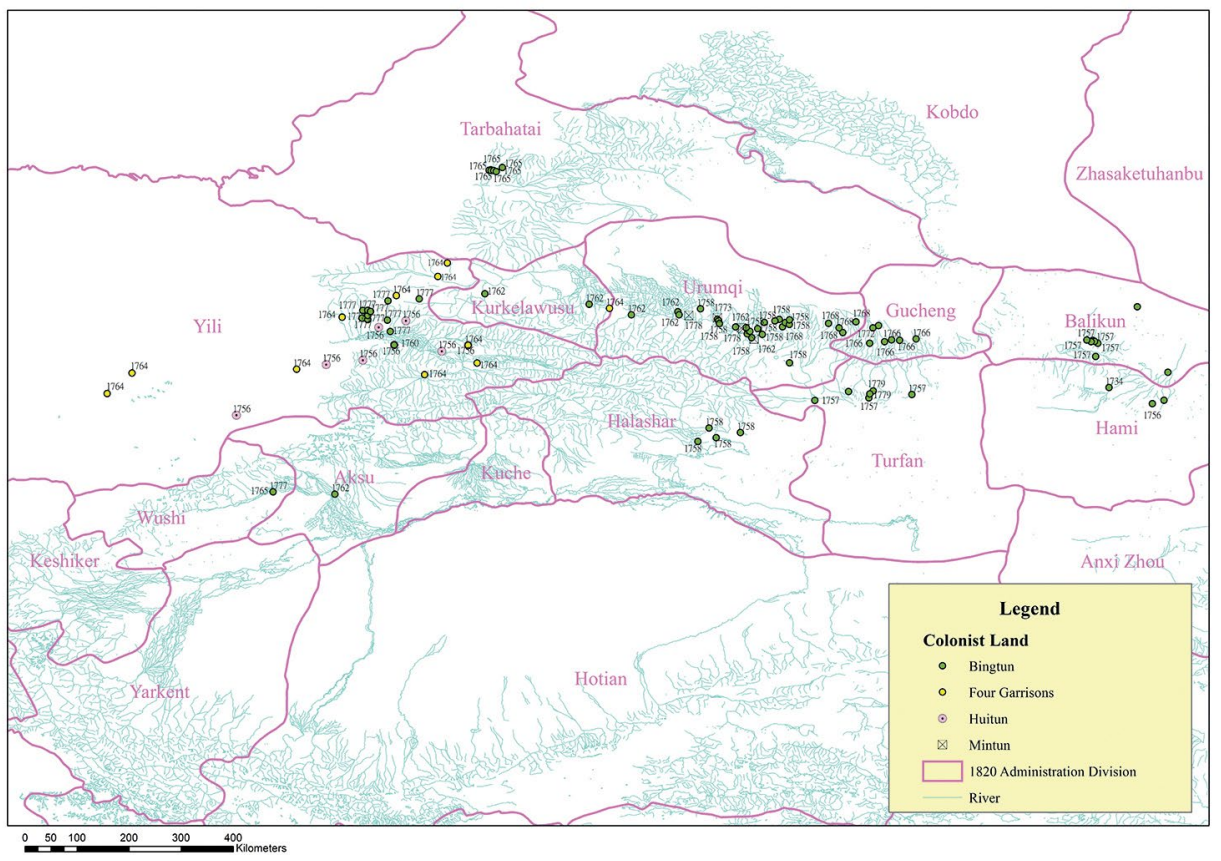

Map 3: The distribution of Tuntian in Xinjiang: The middle stage (1756-78).

In the later stage, 72 colonies of Bintung, Qiantun, and Mintung existed.

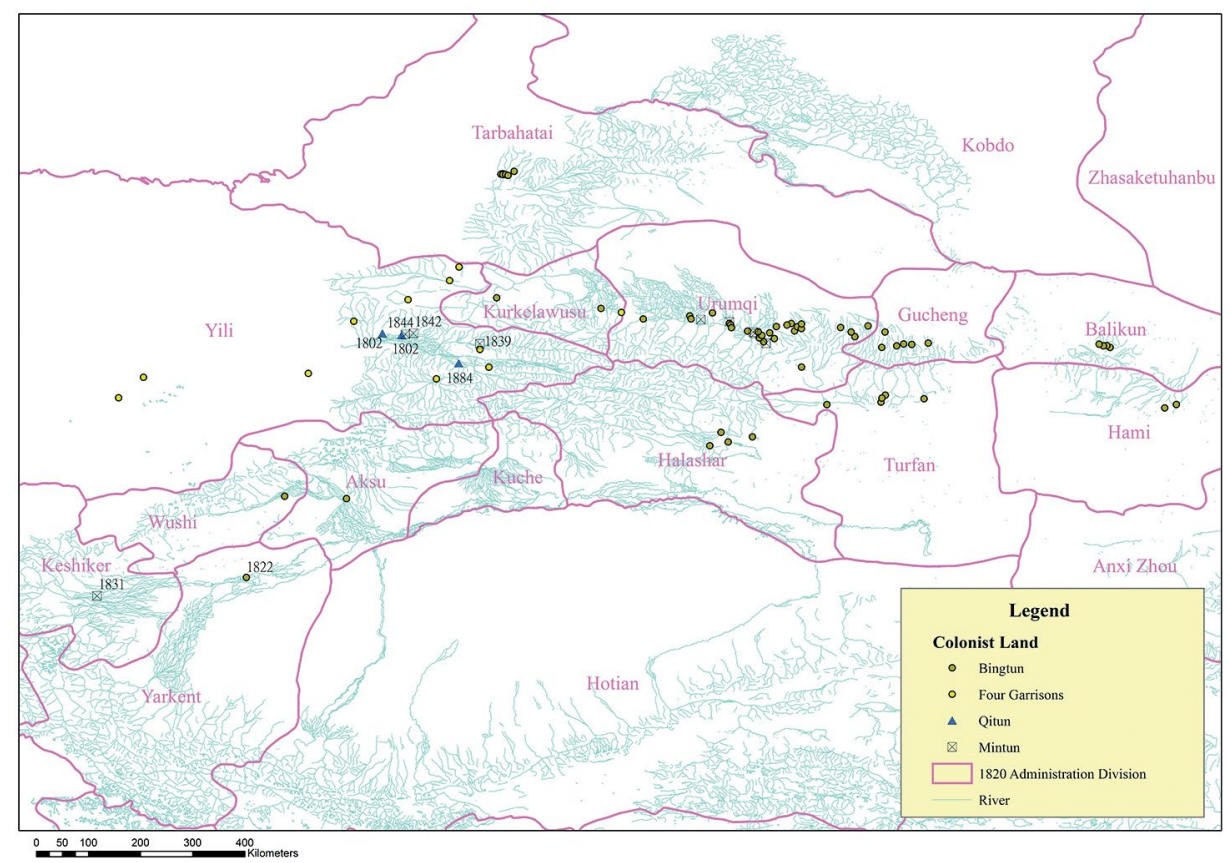

Map 4: The distribution of Tuntian in Xinjiang: The later stage (1802-84). 
As mentioned before, the total land area tilled by the colonists in Xinjiang was 3,020,000 mou.

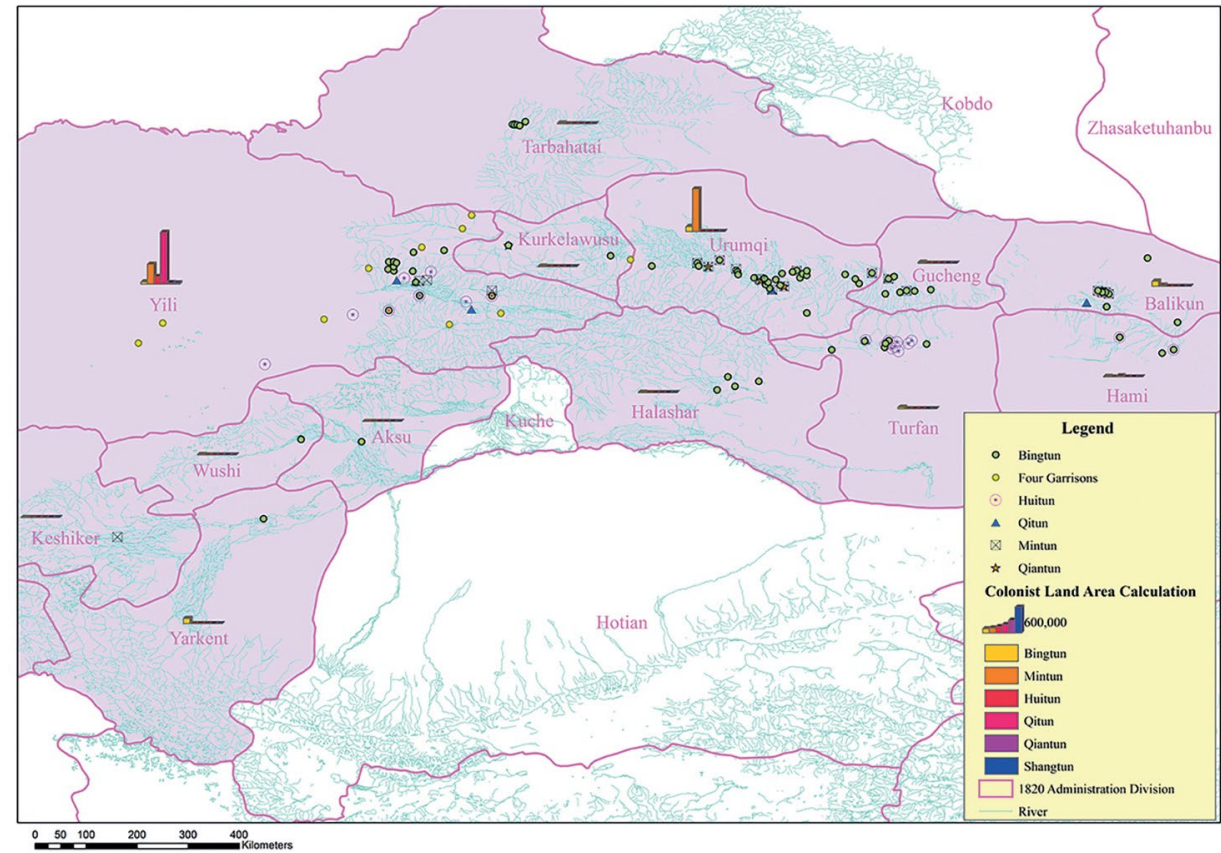

Map 5: The distribution and acreage of each category of Tuntian at various locations.

We next discuss the distribution of the colonised lands developed at various localities, using GIS maps.

\subsection{Bingtun and Mintun at Balikun (see Map 6)}

Balikun, located at the eastern end of the northern slope of the Tianshan Mountain, was in a strategic position. In spring 1716, a Bingtun of the Green Standard Army was established with 500 soldiers to cultivate the land. Thereafter, the military forces at Balikun were strengthened with 23 garrisons of Manchu and Mongol Banners within a radius of $200 \mathrm{li}$ 里 $(100 \mathrm{~km})$. Correspondingly, the Bingtun system was also expanded. Three Bingtun were set up at Tuhuluke (圖呼魯克), Durborjin (杜爾博爾金) and Kara-usu (哈喇烏蘇). In 1726 when the Qing Government negotiated peace with the Dzungar, the Bingtun were abandoned. In 1729, the Qing Army, led by the Ningyuan (寧遠) General Yue Zhongqi 岳鍾琪 (1686-1754), entered Balikun and established Bingtun again. According to Yue's report, more than 5,000 soldiers of the Green Standard Army were sent to cultivate the land. If it is estimated at 20 mou per soldier, then the 
total area of Bingtun at Balikun was 100,000 mou, which made it the largest Bingtun in Xinjiang. In 1734, the Qing and the Dzungar negotiated for peace, the Qing Army was withdrawn, and Bingtun were abandoned for a second time. ${ }^{24}$

In 1757, the Commander Chou Da 丑達 tried to cultivate lands at Puchengzi (朴城子) and Kuisu (奎蘇) under the jurisdiction of Balikun. These two places were originally Bingtun of the western route. At Puchengzi, the land was gradually brought into cultivation using irrigation channels built by soldiers from the Gan, Liang, and Su garrisons. Later, the quota of soldiers increased to 500 and the land area to 20,000 mou, in four villages. At Kuisu, Bingtun were also set up in 1757 by the Gan, Liang, and Su garrisons but were abandoned in $1771 .^{25}$

At Balikun in 1761-64 there were 166 civilian households recruited from the interior to till Mintun land, which totalled more than 12,280 mou. Moreover, 180 civilian households volunteered to come to till the land at Balikun from three counties around Dunhuang (敦煌). In 1765, the Shaan-Gan Governor-General Yang Yingju 楊應琚 (1696-1766), memorialised that 25,000-26,000 mou of land was cultivated by civilians at Balikun, and these lands were irrigated with three channels. In autumn 1771, the Shaan-Gan Governor-General Wen Shou (in office 1771-72) observed that the extended lands were irrigated by the Tianshi (天 時), Dili (地利), Renhe (人和), and Dayou (大有) channels and that they were very beautiful, with abundant crops. The grain was cheap and the households' requirements for their livelihood could be satisfied easily; therefore, more and more people came. ${ }^{26}$

24 Wang, Qingdai xibei tuntian yanjiu, 185-9. In addition, when Lin Zexu was in Hami, the local soldiers and civilians once lodged their complaints against private occupation of land by the Uyghur Chief, Boxier 伯錫 爾. Therefore, Lin Zexu and Quan Qing made a joint announcement pointing out that the land opened by the Uyghur chief at Dongxin zhuang 東新庄 was private; that, after being measured, the total area was more than $10,000 \mathrm{mou}$, including the uncultivated areas; and these lands were all included in the quota for cultivation. See Qi Qingshun 齊清順, ‘Lin Zexu Hami kantian xintan—cong xinjian Lin Zexu soxie de bugou xinjian tanqi' 林則徐哈密勘田新探一從新見林則徐所寫的布告、信件談起 [A new exploration of Lin Zexu's land investigation at Hami - a discussion from the newly discovered announcements and letters of Lin Zexu], Xibei Yanjiu 西北研究 [Northwest Studies] 2 (1997): 17-28.

25 Wang, Qingdai xibei tuntian yanjiu, 42-3.

26 Wang, Qingdai xibei tuntian yanjiu, 48. Based on records in the Comprehensive Scrutiny of Documents: Qing Dynasty (淸朝文獻通考) (Taipei: Xinxing shuju, 1963) and The Veritable Record of the Qianlong Reign [大淸高宗純(乾隆)皇帝實錄], ed. Qing Gui 慶桂 (Taipei: Hualian Publishing Co. 華聯出版社，1964). 


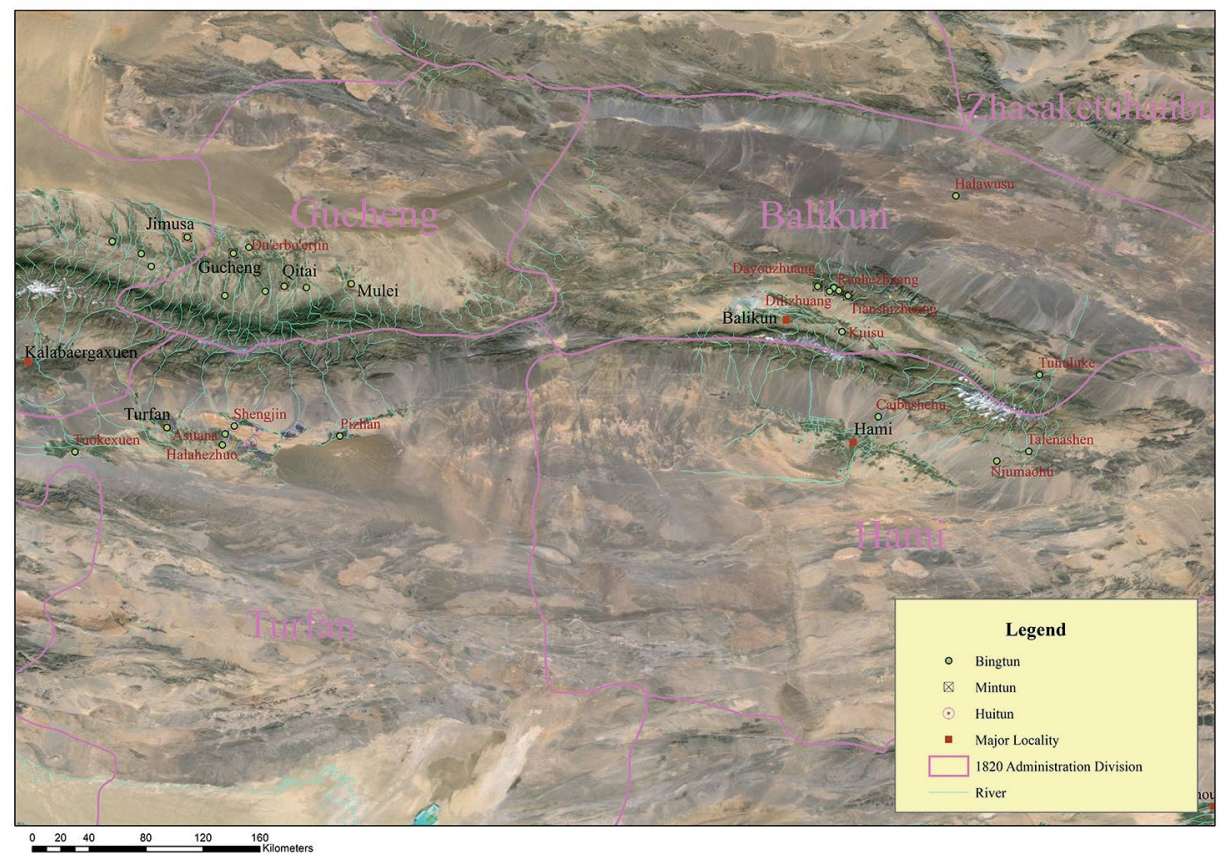

Map 6: The distribution of Tuntian at Balikun and Hami.

\subsection{Bingtun and Huitun at Hami (see Map 6)}

Bingtun at Hami were founded at Talenaqin (塔勒納沁) and Caibashihu (蔡把什湖), located respectively at 120 li and 20 li to the north-east of Hami city. In 1724, more than 1,700 shi (石, a unit of weight) of grain tax were collected at Talenaqin. In the 1730s when the Qing Government negotiated peace with the Dzungar, the Bingtun system was retained at Talenaqin and the grain tax was used to supply soldiers stationed at Hami as well as for animal feed. In 1742, the harvest was poor and sowing was suspended. In 1734, the Deputy General Zhang Guangsi 張廣泗 (d. 1748) appointed some subordinates to investigate at Caibashihu and obtained 50,000 mou of land that could be planted with 5,000 shi of seeds. He ordered soldiers to build irrigation channels and to cultivate the land in order to pay taxes to support the garrison army. In 1739, the Guyuan (固原) Commander Li Shengwu 李繩武 (d. 1757) memorialised that the Green Standard Army from the Gan and Liang garrisons had cultivated 10,000 mou of land at Caibashihu and harvested a total of 9,253 shi of wheat and millet. But in 1742, the Bingtun was withdrawn and the land was given to the Uyghur to cultivate and enable them to pay taxes. 
After the withdrawal of the Bingtun at Hami in 1742, the irrigation channels silted up and the land lay in waste. In 1756, the Shaan-Gan Governor-General Huang Tingkui 黃廷桂 (1691-1759) memorialised to assign officers and soldiers to cultivate the land. In the next year, the soldiers started to dredge the irrigation channels and three colonies were established in turn. The first one, located at Talenaqin, had 5,000 mou of land and 200 soldiers; the second one, at Caibashihu, had 4,000 mou of land and 100 soldiers, and the third one, at Niumaohu (牛毛湖), had 200 mou of land, confiscated from the lieutenant in charge of the colonists' land. ${ }^{27}$

Huitun at Hami were also established at Talenaqin and Caibashihu. According to a memorial (dated 17 November 1718) of the Attending Official Hai Shou 海 壽, prior to 1718 , the Huitun at Talenaqin was cultivated by the Uyghur, led by Emin Hezhuo 額敏和卓 (1694-1777). The land was a part of the Bingtun on the West Route. Moreover, granaries were built at Talenaqin to supply the Qing Army. In 1720, the Qing Army occupied Turfan and established Bingtun with garrison soldiers. Emin led his people to cultivate the land at Turfan. In 1723, owing to the fact that the Uyghur were not accustomed to the climate there, he appealed to the Qing Government to allow 400 Uyghur to return to Hami to cultivate the land at Talenaqin. Afterwards, the scale of the Huitun was enlarged. In 1730, the harvest of wheat and highland barley (qingke 青稞) reached 6,400 shi and the annual planting of 500 shi of seed and tax payment of 4,000 shi of grain became standard practice. In 1736, Emin memorialised that the annual payment of grain from Huitun at Hami amounted to 27,500 shi.

At Caibashihu, Huitun was established in 1712. At that time, because 300 soldiers at Hami were withdrawn, it was impossible for the remaining soldiers to cultivate the original area of land; therefore, the Chuan-Shaan GovernorGeneral Yin Jishan 尹繼善 (1695-1771) transferred 10,000 mou of Bingtun land at Caibashihu to the Uyghur. In 1753, Yusuf Khass, who was given the title of Hami Beise (貝子), reported that the Uyghur were too exhausted to cultivate the land. The local official investigated and discussed the matter with Yin Jishan, deciding that the Uyghur could cultivate the land with no obligation to turn in their harvest to Qing officials. This meant that the Huitun at Caibashihu was suspended. ${ }^{28}$

27 Wang, Qingdai xibei tuntian yanjiu, 177-8.

28 Wang, Qingdai xibei tuntian yanjiu, 44. 


\subsection{Bingtun and Huitun at Turfan (see Map 7)}

Turfan neighbours Hami and is at the junction of roads leading to both northern and southern Xinjiang. In 1678, Galdan 噶爾丹 (1644-1697), the leader of the Dzungar, occupied southern Xinjiang and controlled 17 cities around Turfan. In 1715, the Qing Army of the West Route entered Balikun. In 1720, General Fu Ningan 富寧安 (d. 1728) attacked Urumqi and in 1721 the Qing Army entered Turfan. They immediately moved in cattle and seed to establish Bingtun. But at Turfan, the Bingtun system was suspended after 1725. In 1729, the Qing Army entered Balikun again and some soldiers were also sent to Turfan to cultivate the land together with the Uyghur. From April 1731 to June 1732, the Dzungar attacked Luguqing (魯谷慶) and Halahuozhou (哈喇火州) four times, preventing the parts of the Qing Army distributed among seven cities contacting each other. The Qing Army at Balikun went to help several times and became exhausted. In November 1732, the Qing Government moved the Uyghur living at Turfan to Guazhou (瓜州), and about the same time the Qing Government gave up the Bingtun at Turfan. ${ }^{29}$

In 1757, when Bingtun were established again at Turfan, they were located at Pizhan (辟展), Halahozho (哈喇和卓), and Tokesun (托克遜). In 1760, Pizhan had 13,633 mou of land and 800 soldiers; Halahozho had 6,000 mou of land and 300 soldiers; and Tokesun had 14,253 mou of land and 1,000 soldiers. In 1761-62, the colonist soldiers at Turfan were moved to Urumqi and Yili and the land was transferred to the Uyghur; after that, there was no Bingtun at Turfan. In 1779, the Turfan Marquis Su Laiman 蘇賚璊 (d. 1780) was convicted and his private property, with 14,700 mou of land, was confiscated. It was distributed to seven Bingtun with 700 soldiers as follows: Tokesun (100), Anzhan (安展， 250), Halahozho (100), Asitana (阿斯塔納, 100), Hesertula (和色爾圖喇, 50), Shengjin (勝金, 50), and Pizhan (50). ${ }^{30}$

At about the same time as the Bingtun system was established at Turfan, the Uyghur led by Emin Hezhuo also started to cultivate the Huitun land. He submitted to Qing authority in 1720 and led his people to cultivate the land and pay taxes for seven years; his contribution was praised by the Qing Government. In 1731，Galdan Tseren 噶爾丹策零 (1695-1745) attacked Turfan several times, so the Qing Army moved east. In 1732, more than 10,000 Uyghur living in cities around Turfan followed the Qing Government's suggestion and moved east, led by Emin Hezhou. They first arrived at Talenaqin, and the following year moved further east to Guazhou. As there were great losses during the journey,

29 Wang, Qingdai xibei tuntian yanjiu, 48.

30 Wang, Qingdai xibei tuntian yanjiu, 197-201. Hai Shou's memorial was recorded in The Veritable Record of the Kangxi Reign [大清聖祖仁(康熙)皇帝實錄], ed. Ma Qi 馬齊, Zhang Tingyu 張廷玉, and Jiang tingxi 蔣廷錫 (Taipei: Hualian Publishing Co. 華聯出版社, 1964). 
only 8,013 persons (including men, women, and children) arrived at Guazhou in September 1732. The Qing Government had the Uyghur settle down at five castles. In 1755, the government again sent the army to pacify the Dzungar. Emin Hezhou followed the Qing Army to Turfan to investigate the local situation and he obtained an agreement with the Qing Government to move back to Turfan from Guazhou. From 1733 to 1756, the Uyghur lived at Guazhou and made a considerable contribution to the cultivation of land there. ${ }^{31}$

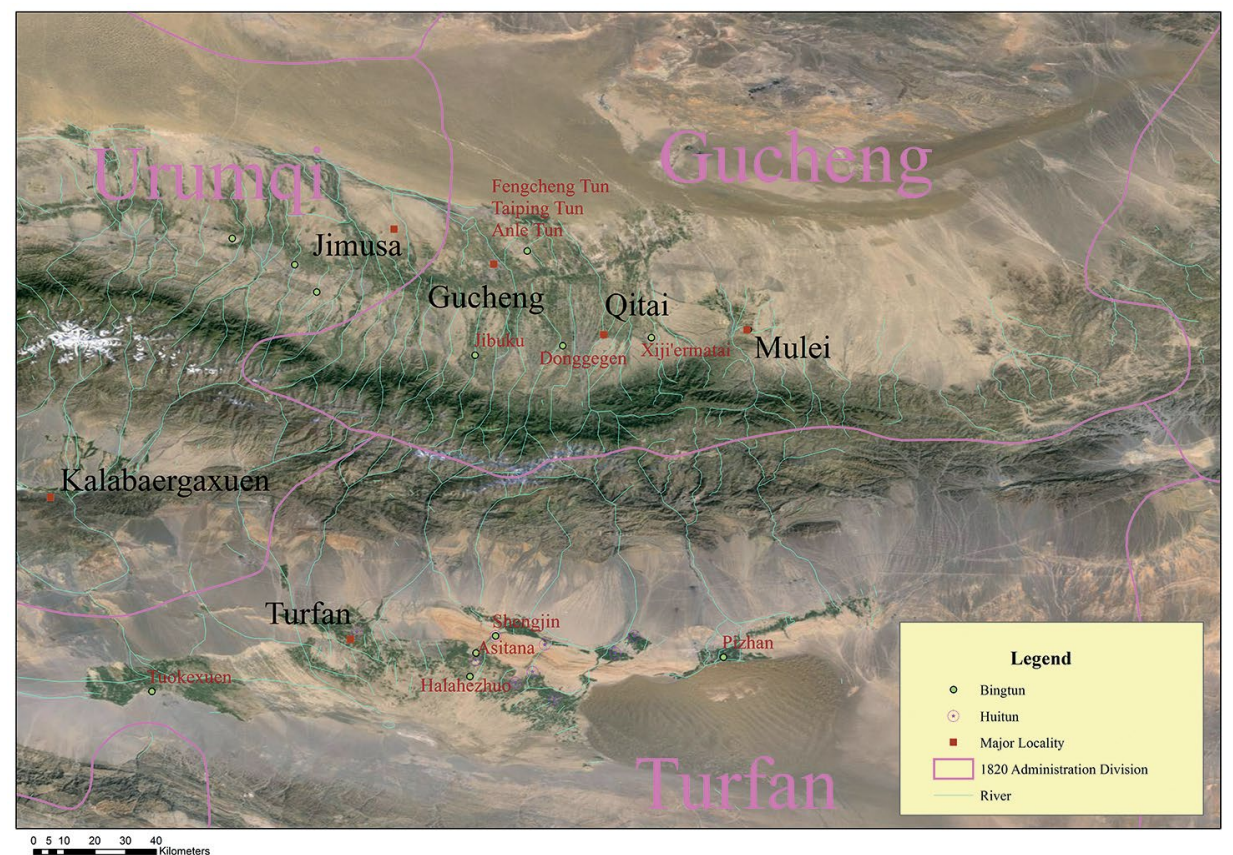

Map 7: The distribution of Tuntian at Turfan and Gucheng.

\subsection{Bingtun at Gucheng (see Map 7)}

At Gucheng, Bingtun lands were developed at Mulei and Qitai (奇台) in 1766. Later, the quota of the soldiers was set at 500 and the land at 10,000 mou, to be distributed at Mulei, Qitai, Xijirmatai (西濟爾瑪台), Donggegen (東格 根), and Jibuku (吉布庫). In 1770, these Bingtun were abandoned and the soldiers withdrawn, with only 150 soldiers and 3,300 mou of land retained at Jibuku. Moreover, at Gucheng, Bingtun were started in 1772 with 500 soldiers and 12,100 mou of land distributed at Fensheng (豐盛), Taiping (太平), and Anle (安樂). 


\subsection{Bingtun, Mintun and Qiantun at Urumqi (see Map 8)}

Bingtun were set up at the Middle, Left, and Right garrisons of Urumqi in 1758; at Manas in 1762; and at Jimusa (濟木薩) in 1768. Table 1 shows the scale of Bingtun at Urumqi in 1777. Altogether 109,000 mou of land and 5,473 soldiers were distributed among 36 locations.

Table 1: The scale of Bingtun at Urumqi in 1777.

\begin{tabular}{|c|c|c|c|}
\hline Location & Land (mou) & Soldiers & Distribution of soldiers \\
\hline Middle Garrison & 22,000 & 1,066 & $\begin{array}{l}133 \text { each at Jihuaicheng (輯懷城); Tudunzi (土墩子), } \\
\text { Huaiyibao (懷義堡), Lufengboo (屢豐堡), Xuanrenbao } \\
\text { (宣仁堡), Huilaibao (惠徠堡); } 90 \text { each at Toudaowan } \\
\text { toukong (頭道灣頭工) and Toudaowan erkong (頭道灣 } \\
\text { 二工); and } 88 \text { at Fukangcheng (阜康城). }\end{array}$ \\
\hline Left Garrison & 22,000 & 1,066 & $\begin{array}{l}148 \text { each at Toukong (頭工), Erkong (二工), Sankong } \\
\text { (三工) and Sikong (四工); } 147 \text { each at Baochangbao } \\
\text { (寶昌堡) and Lequanbao (樂全堡); and } 90 \text { each at } \\
\text { Ganbiao Toutun (甘標頭屯) and Ganbiao Ertun (甘標 } \\
\text { 二屯). }\end{array}$ \\
\hline Right Garrison & 22,000 & 1,066 & $\begin{array}{l}153 \text { each at Toukong (頭工), Erkong (二工), Sankong } \\
\text { (三工), and Sikong (四工); } 152 \text { each at Wukong (五工) } \\
\text { and Liukong (六工); and } 150 \text { at Tugulike (土古里克). }\end{array}$ \\
\hline Manas & $28,000^{*}$ & 1,400 & $\begin{array}{l}\text { The Left and Right garrisons each had } 7 \text { Bintun each } \\
\text { had } 100 \text { soldiers. }\end{array}$ \\
\hline Jimusa & $15,000^{\star \star}$ & 875 & $\begin{array}{l}230 \text { each at Jimusa (吉木蕯) and Shuangchahe (雙忿 } \\
\text { 河); } 201 \text { at Santai (三台); } 155 \text { at Liushuhe (柳樹河); } \\
\text { and } 50 \text { at Tenagercha (特訥格爾差). }\end{array}$ \\
\hline Total & 109,000 & 5,473 & \\
\hline
\end{tabular}

* 1,700 mou in $1768 ;{ }^{*} 20,000$ mou in 1768 .

Source: This table is based on Wang, Qingdai xibei tuntian yanjiu, 49.

As for Mintun at Urumqi, Table 2 shows the origin and number of civil households at Urumqi during 1762-78. With regard to their origins, 'With local agreement' and 'New local recruitment' were more common than other sources. In the course of 17 years, 'From the interior' was recorded only in 1762, $1765,1766,1772,1777$, and 1778, while in other years, civilians came mostly as a result of local agreement, local new recruitment, divisions of households among soldiers' descendants, merchants moving in their families, and divisions of Vietnamese households. Those who came from the interior were mostly from Suzhou, Ganzhou, Anxi, and Dunhuang. ${ }^{32}$ 
In addition to the numbers listed in Table 2, 10,454 households were moved from Gansu to Balikun and Urumqi in $1761-80 .{ }^{33}$ However, the actual number was much larger. For instance, a memorial dated 13 September 1777 by the Urumqi Commander Sonomu Celing 索諾穆策凌 (1739-82) reported that since 1761, 11,741 households had moved to Urumqi and other places; in 1778, he reported a further 11,854 poor households had moved there. ${ }^{34}$ Moreover, around 1778, there were 9,293 civil households, of which 5,133 had paid tax. Each household cultivated 30 mou of land, the total being 153,990 mou. Each mou paid 0.08 shi of fine grain in tax; in total 12,319.2 shi of fine grain was paid. Those not yet paying the tax comprised 4,260 households. ${ }^{35}$

Table 2: The origin and distribution of civil households at Urumqi (1762-78).

\begin{tabular}{|c|c|c|c|}
\hline Year & Origins & Location and Number of Households & Total \\
\hline 1762 & From the interior & Dihua (迪化) 216, Ningbian (寧邊) 210 & 426 \\
\hline 1763 & With local agreement & Dihua 134 , Ningbian 43 & 177 \\
\hline 1764 & With local agreement & Dihua 28, Ningbian 89, Fukang (阜康) 102 & 219 \\
\hline 1765 & $\begin{array}{l}\text { From the interior and } \\
\text { with local agreement }\end{array}$ & Dihua 125, Ningbian 866, Fukang 15 & 1,006 \\
\hline 1766 & $\begin{array}{l}\text { From the interior and } \\
\text { with local agreement }\end{array}$ & Dihua 107, Ningbian 573, Fukang 909 & 1,589 \\
\hline 1767 & With local agreement & Dihua 76, Ningbian 100, Fukang 179 & 355 \\
\hline 1768 & With local agreement & Dihua 79, Ningbian 126, Fukang 66 & 271 \\
\hline 1769 & With local agreement & Dihua 22, Ningbian 18, Fukang 37 & 77 \\
\hline 1770 & With local agreement & Dihua 10, Ningbian 25, Fukang 15 & 50 \\
\hline 1771 & Local recruitment & Dihua 6 , Ningbian 19, Fukang 6 & 31 \\
\hline \multirow[t]{3}{*}{1772} & $\begin{array}{l}\text { Merchants with } \\
\text { agreement }\end{array}$ & Dihua 20, Ningbian 12 & 32 \\
\hline & From the interior & Jimusa (濟木薩) 400 & 400 \\
\hline & Merchants with wives & $?$ & 126 \\
\hline \multirow[t]{2}{*}{1773} & With local agreement & $\begin{array}{l}\text { Dihua 117, Changji (昌吉) 29, Jimusa 205, } \\
\text { Jinghua (景化) } 26\end{array}$ & 377 \\
\hline & Merchants with wives & Dihua 2, Changji 2 & 4 \\
\hline 1774 & With local agreement & Dihua 74, Changji 48 & 122 \\
\hline 1775 & Local recruitment & Dihua 118, Fukang 1, Jimusa 2, Changji 81 & 202 \\
\hline 1776 & Local recruitment & Dihua 110, Fukang 18, Jimusa 13, Changji 9 & 150 \\
\hline
\end{tabular}

33 Hua Li 華立, Qingdai Xinjiang nongyeh kaifashi 淸代新疆農業開發史 [History of Agricultural Exploitation in Xinjiang during the Qing Dynasty] (Harbin: Heilongjiang Education Press, 1998), 61-4.

34 China's First Archives 中國第一檔案館, ‘Qianlong nianjian ximin tunken Xinjiang shiliao 乾隆年間徙 民屯墾新疆史料' [The source materials of migrants to the colonized land in Xinjiang during the Qianlong Reign], Lishi danan 歷史檔案 [Historical Archives] 2 (2002): 27, 29.

35 Urumqi zhenglüe 鳥魯木齊政略 [A Brief of Political Affairs at Urumq], cited in Wang Xilong 王希隆, Xinjiang wenxian sizhong jizhu kaoshu 新疆文獻四種輯注考述 [Annotation and Verification of Four Collections of Xinjiang Documents] (Lanzhou: The Gansu Documentary Press, 1995), 59. 


\begin{tabular}{|c|c|c|c|}
\hline Year & Origins & Location and Number of Households & Total \\
\hline \multirow[t]{3}{*}{1777} & From the interior & Fukang 120, Hutubi (呼圖壁) 94, Manas (瑪納斯) 428 & 642 \\
\hline & $\begin{array}{l}\text { Divided households of } \\
\text { soldiers' descendants }\end{array}$ & Manas 278 & 278 \\
\hline & Local recruitment & Dihua 319, Jimusa 8, Changji 52 & 379 \\
\hline \multirow[t]{7}{*}{1778} & $\begin{array}{l}\text { Divided households of } \\
\text { soldiers' descendants }\end{array}$ & Manas 102, Gucheng (古城) 46 & 148 \\
\hline & From the interior & $\begin{array}{l}\text { Qitai (奇台) and other places 530, } \\
\text { Tugukeli (土古克里) } 165\end{array}$ & 695 \\
\hline & New local recruitment & Dihua 180, Jimusa 21, Changji 29 & 230 \\
\hline & $\begin{array}{l}\text { Divided households of } \\
\text { soldiers }\end{array}$ & Qitai 37 & 37 \\
\hline & $\begin{array}{l}\text { Divided households of } \\
\text { Vietnamese at Dihua }\end{array}$ & Dihua 11 & 11 \\
\hline & $\begin{array}{l}\text { Divided households of } \\
\text { local aborigines }\end{array}$ & $\begin{array}{l}\text { Toutun (頭屯) 39, Lucaogou (蘆草溝) 45, } \\
\text { Taxihe (塔西河) } 46\end{array}$ & 130 \\
\hline & $\begin{array}{l}\text { Merchants moved their } \\
\text { families to the colonies }\end{array}$ & $\begin{array}{l}\text { Dihua 559, Fukang } 173 \text {, Jimusa } 287 \text {, Changji } 65 \text {, } \\
\text { Manas } 33, \text { Hutubi } 19\end{array}$ & 1,136 \\
\hline Total & & & 9,300 \\
\hline
\end{tabular}

Source: This table was prepared by the authors based on the anonymous Urumqi zhenglüe 鳥魯木齊 政略 [A Brief of Political Affairs at Urumq], cited in Wang Xilong 王希隆, Xinjiang wenxian sizhong jizhu kaoshu新疆文獻四種輯注考述 [Annotation and Verification of Four Collections of Xinjiang Documents] (Lanzhou: The Gansu Documentary Press, 1995), 57-9.

The total acreage of Mintun was $987,789.3$ mou, including three items: the land cultivated continuously from 1762 on, the land obtained during the measurements in 1786-87, and the Bingtun land withdrawn from Jimusa in 1790. Of the total acreage, 683,686.2 mou was distributed among six Mintun at Dihua, Changji, Suilai, Fukang, Jimusa, and Hutubi; this acreage consisted of 458,624 mou originally transferred, 14,451 mou withdrawn from Jimusa, and the extra 210,611.2 mou found in the measurement. At Toutun, Lucaogou, and Taxihe there were 44,210.7 mou, of which 42,793 mou was originally transferred and the extra 1,417.7 mou was found in the measurement. At Yihe and Qitai of Zhengxi Prefecture, there was 259,892.4 mou, of which 162,729.3 mou was originally transferred and the extra 97,163.1 mou was found in the measurement. ${ }^{36}$ It is notable that the extra land found in the measurement

36 Yong Bao 永保, comp., Urumqi shiyi 鳥魯木齊事宜 [Matters concerning Urumqi], cited in Wang, Xinjiang wenxian sizhong jizhu kaoshu, 127-8. 
formed 32 per cent of the total, and the land originally transferred 46 per cent at Dihua, even reaching 60 per cent at Yihe. The large percentage of extra land revealed that Mintun was very active in the early stage of development.

Table 3 shows the number of households and the population at the end of 1795 . Compared with 9,300 households up to 1778, the 20,787 households in 1795 indicated that the number more than doubled in 17 years.

Table 3: The population of civil households in Urumqi (1795).

\begin{tabular}{|c|c|c|c|}
\hline \multirow[t]{2}{*}{ Location } & \multicolumn{3}{|c|}{ Civil Households } \\
\hline & Households & Males & Females \\
\hline Dihua zhou 迪化州 & 3,326 & 14,322 & 12,386 \\
\hline Changji xian 昌吉縣 & 3,252 & 8,847 & 6,665 \\
\hline Suilai xian 綏來縣 & 2,913 & 6,661 & 4,664 \\
\hline Fukang xian 阜康縣 & 1,964 & 6,102 & 5,032 \\
\hline Jimusa濟木薩 & 2,674 & 7,502 & 5,336 \\
\hline Hutubi呼圖壁 & 1,064 & 4,942 & 2,838 \\
\hline Kelabarkesun喀喇巴爾噶猻 & 200 & 607 & 505 \\
\hline Zhenxi fu 鎭西府Yihe xian宜禾縣 & 601 & 3,931 & 2,889 \\
\hline Zhenxi fu Qitai xian 奇台縣 & 3,426 & 18,422 & 12,703 \\
\hline Toutun 頭屯 * & 447 & 1,085 & 467 \\
\hline Lucaogou蘆草溝* & 496 & 990 & 444 \\
\hline Taxihe塔西河* & 424 & 1,064 & 280 \\
\hline Total 合計** & 20,787 & 74,475 & 54,209 \\
\hline
\end{tabular}

* The original text said at 'These three places are civil colonists'. This should refer to the exiled criminals who chose to stay in the locality at the end of their designated term.

** The total numbers are slightly different from the original records of 20,662 households with a total population of 129,642 men, women, and children.

Source: This table was prepared by the authors based on Yong Bao 永保, comp., Urumqi shiyi 鳥魯木 齊事宜 [Matters concerning Urumqi], cited in Wang, Xinjiang wenxian sizhong jizhu kaoshu, 126-7.

In addition to civil households, in 1795, 11,545 merchant households were included in the local policing system (Baojia 保甲) at Urumqi, with a total population of 43,791. These merchant households were different from those engaged in the local market gardening business. Other statistics showed that at Urumqi there were 498 merchant households engaging in market gardening, cultivating 27,090 mou of land. ${ }^{37}$

As for the exiled criminals, Ji Yun 紀盷 (1724-1805), a dismissed official at Urumqi in 1768-71, said in a poem: 'The small houses clustering together were homes of all newly exiled criminals.' He added that exiled criminals resided in 
Changji, Toutun, and Lucaogou. ${ }^{38}$ During the Qianlong period, the number of exiled criminals converted to civilian households was as follows: Toutun 512, Lucaogou 505, and Taxihe 225; together there were 1,242 households, of which 1,234 paid taxes. They cultivated 30 mou each and altogether they cultivated 37,020 mou of land. ${ }^{39}$ Compared with the number listed in Table 3, in 1795 there were 447 households at Toutun, 496 at Lucaogou, and 424 at Taxihe. In 1842 when Lin Zexu was on the way to Yili, he noted at Taxihe: 'There are several hundreds of descendants of exiled criminal households from Zhangzhou (漳州) and Quanzhou (泉州). In recent years, exiled criminals from Fujian and Guangdong provinces were also dispatched to Taxihe.' ${ }^{\prime 40}$

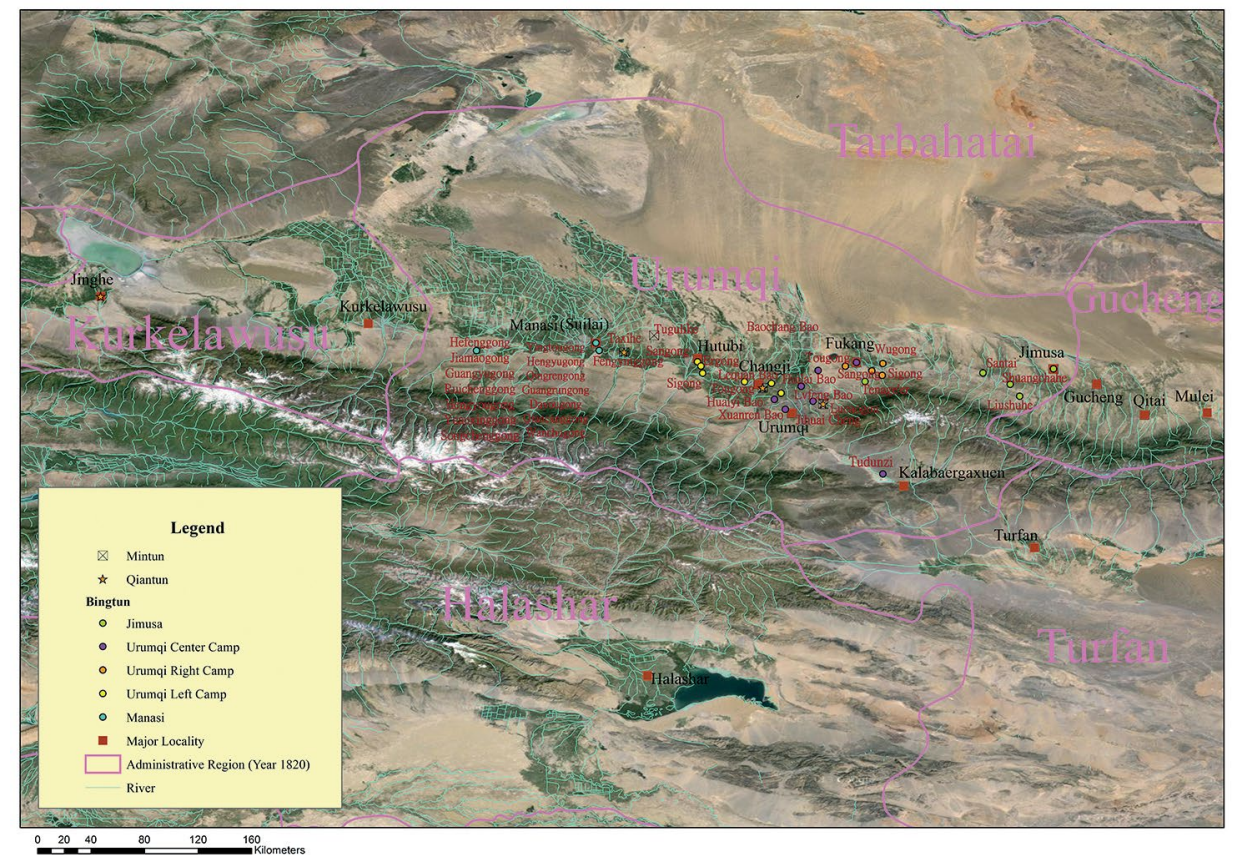

Map 8: The distribution of Tuntian at Urumqi, Kurkelawusu, and Jinghe.

38 Ji Yun, Urumqi zashi 鳥魯木齊雜詩 [Miscellaneous Poems written at Urumqi], in Wang, Xinjiang wenxian sizhong jizhu kaoshu, 170.

39 Anonymous, Urumqi zheng-lüe, 59.

40 Lin Zexu 林則徐, Hege jicheng 荷戈紀程 [Record of journey carrying an axe], an edition of Xiaofanghuzhai chaoben (小方壳齋叢鈔本) included in Xu Lihua 徐麗華, ed., Zhongguo shaoshu minzu guji jicheng 中國少 數民族古藉集成 [Collection of Ancient Books of China's Nationalities] (Chengdu: Sichuan Nationality Press, 2002), 76: 558 . 


\subsection{Bingtun at Kurkelawusu and Jinghe (see Map 8)}

Bingtun at Kurkelawusu and Jinghe were established in 1762: Kurkelawusu had 5,400 mou of land and 270 soldiers, and Jinghe had 4,050 mou of land and 270 soldiers. In 1765, the numbers were reduced: Kurkelawusu had 3,636 mou of land and 180 soldiers, and Jinghe had 3,360 mou of land and 168 soldiers. Lin Zexu observed in 1842 there were more than 200 exiled criminals settled at Jinghe and they were all engaged in cultivating the land and providing services. Half of these exiled criminals were from Fujian and Guangdong provinces. $^{41}$

\subsection{Bingtun at Tarbahatai and Halashar (see Map 9)}

Bingtun at Tarbahatai started in 1765. In 1777, there were 17,000 mou of land and 850 soldiers. In 1794, the number of soldiers was reduced to 400 and distributed among five colonies with 80 soldiers each. The locations of these colonies relative to Tarbahatai were as follows: Toukong at 4 li to the west, Erkong at 2 li to the south, Sankong at $8 \mathrm{li}$ to the south-east, Sikong at $12 \mathrm{li}$ to the south-east, and Wukong at 30 li to the east. Together they cultivated 8,000 mou of land. ${ }^{42}$

Bingtun at Halashar were set up in 1758 and by the next year had 9,675 mou of land. In 1777, there were 362 soldiers and 7,440 mou of land. The colonies were at three locations near Halashar: Toukong at 60 li to the north-east, Erkong at 70 li to the east, and Sankong at 220 li to the east; the last place was also known as Wushaketar (烏沙克塔爾). ${ }^{43}$

41 Lin Zexu, Hege jicheng, 76: 558.

42 Wang, Qingdai xibei tuntian yanjiu, 50.

43 Wang, Qingdai xibei tuntian yanjiu, 51. 


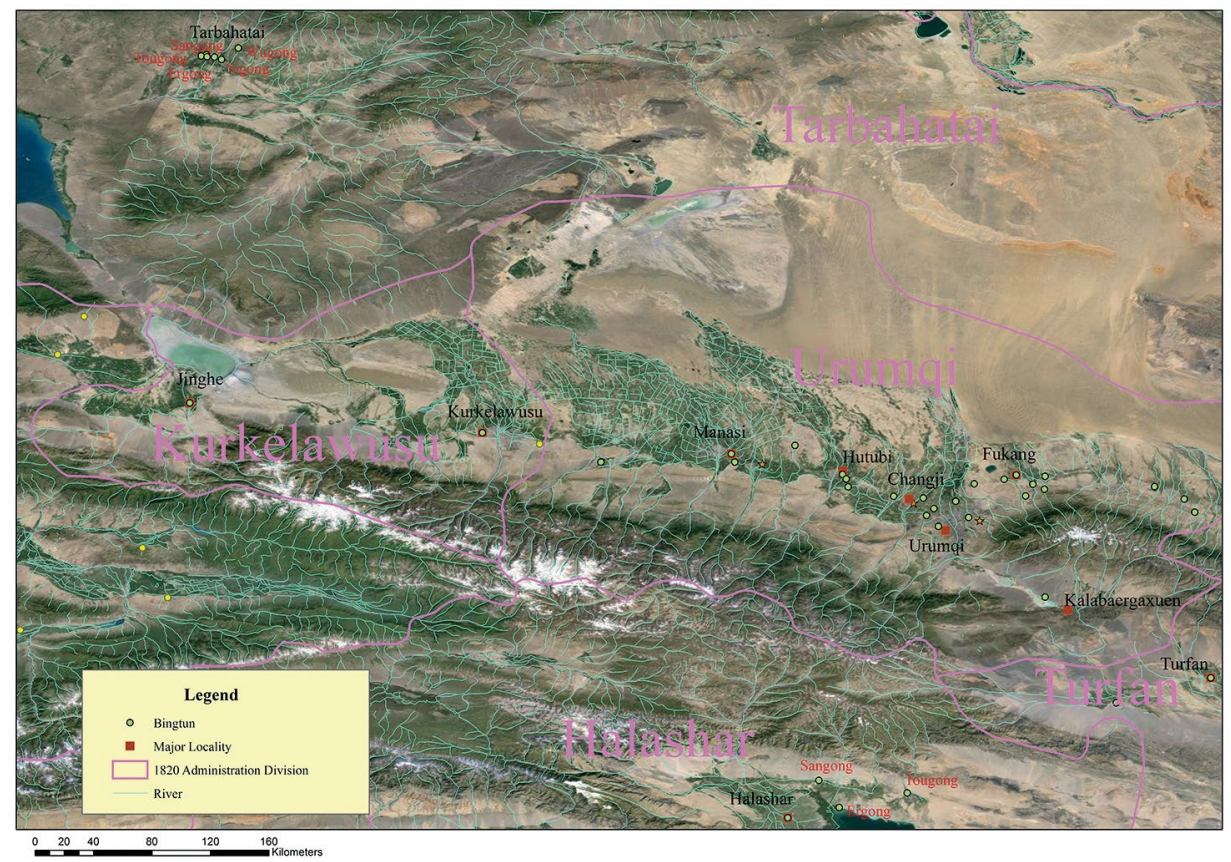

Map 9: The distribution of Tuntian at Tarbahatai and Halashar.

\subsection{Bingtun, Qitun, land of Four Garrisons, and Huitun at Yili (see Map 10)}

Bingtun at Yili began in 1760, and some 16,000 mou of land was opened up in the following year. In 1777, the acreage increased to 50,588 mou and the number of soldiers to 2,500. At Yili, Bingtun were divided into 25 units, each with 100 soldiers, as follows: Lamagou (喇嘛溝) and Lucaogou (蘆草溝), located to the north of Suiding (綏定) city, had one unit each; Tarqi (塔爾奇) city had three units; Huoerguosi (霍爾果斯), to the west of Tarqi, had three units; Chahanwusu (察漢烏蘇) had seven units; to the north-west of the city, Qingshuihe (清水河) had two units; Dushanzi (獨山子) had one unit; and to the north of the city, Daxigou (大西溝) had two units; Dadonggou (大東溝) and Xiaodongguo (小東溝) each had one unit; to the south, Huining city had three units. $^{44}$

Qitun of the Eight Banners garrisons at Yili were started in 1802 by General Song Yun. Irrigation channels were built and 120,000 mou of land was conferred on Eight Banners garrisons at Huiyuan and Huining. These lands were distributed in 14 units, of which Huiyuan had 9 and Huining had 5, as is shown in Table 4. 
Table 4: Qitun at Huiyuan and Huining in Yili.

\begin{tabular}{|c|c|c|c|}
\hline \multicolumn{2}{|c|}{ Eight Banners Garrisons at Huiyuan } & \multicolumn{2}{|c|}{ Eight Banners Garrisons at Huining } \\
\hline Banner & Location of Land & Banner & Location of Land \\
\hline $\begin{array}{l}\text { Five Zuoling 佐領 } \\
\text { of Bordered White } \\
\text { Banner }\end{array}$ & $\begin{array}{l}\text { South-east of the City: } \\
\text { Hongliuwang (紅柳灣) }\end{array}$ & $\begin{array}{l}\text { Four Zuoling of Plan } \\
\text { Yellow and Plain Red } \\
\text { Banners }\end{array}$ & East of the city \\
\hline $\begin{array}{l}\text { Five Zuoling of Plain } \\
\text { Yellow Banner }\end{array}$ & $\begin{array}{l}\text { North-east of city: } \\
\text { around the mountain area }\end{array}$ & $\begin{array}{l}\text { Four Zuoling of Bordered } \\
\text { Yellow and Plain White } \\
\text { Banners }\end{array}$ & East of the city \\
\hline $\begin{array}{l}\text { Five Zuoling of Plain } \\
\text { Blue Banner }\end{array}$ & $\begin{array}{l}\text { North-east of the city: } \\
\text { Shuiquanzi (水泉子) }\end{array}$ & $\begin{array}{l}\text { Four Zuoling of Bordered } \\
\text { Red and Bordered Yellow } \\
\text { Banners }\end{array}$ & East of the city \\
\hline $\begin{array}{l}\text { Five Zuoling of } \\
\text { Bordered Yellow } \\
\text { Banner }\end{array}$ & $\begin{array}{l}\text { Banner land at Xinbeitun } \\
\text { (新北屯) }\end{array}$ & $\begin{array}{l}\text { Four Zuoling of Bordered } \\
\text { White and Plain Blue } \\
\text { Banners }\end{array}$ & North of the city \\
\hline $\begin{array}{l}\text { Five Zuoling of Plain } \\
\text { White Banner }\end{array}$ & $\begin{array}{l}\text { East of the city: Huitongqu } \\
\text { (通惠渠) and extended to } \\
\text { the north }\end{array}$ & Eight Banner Public Land & $\begin{array}{l}\text { Northwest of the } \\
\text { city }\end{array}$ \\
\hline $\begin{array}{l}\text { Five Zuoling of } \\
\text { Bordered Blue } \\
\text { Banner }\end{array}$ & $\begin{array}{l}\text { East of the city: Fenshuizha } \\
\text { (分水閘) and extended to } \\
\text { the north }\end{array}$ & & \\
\hline $\begin{array}{l}\text { Ten Zuoling of Plain } \\
\text { and Bordered Red } \\
\text { Banner }\end{array}$ & $\begin{array}{l}\text { North-west of the city: } \\
\text { Yikeshu (一棵樹) to the } \\
\text { south-west and north-west }\end{array}$ & & \\
\hline $\begin{array}{l}\text { Eight Banner Public } \\
\text { Land }\end{array}$ & $\begin{array}{l}\text { East of the city: Banner's } \\
\text { rice field }\end{array}$ & & \\
\hline $\begin{array}{l}\text { Eight Banner Public } \\
\text { Land }\end{array}$ & $\begin{array}{l}\text { East of the city: Qiligou } \\
\text { (七里溝) to the east of the } \\
\text { rice field }\end{array}$ & & \\
\hline
\end{tabular}

Source: This table was prepared by the authors based on Wang, 91 .

After Qitun were established at Yili, changes appeared very soon. First, the undivided public land of the Eight Banners was converted to land managed by each Banner. In 1812, after a survey by the Yili General Jin Chang 育昌 (1759-1828), more than 20,000 mou of the public land, which was expected to receive irrigation water, was divided into eight parts for the Eight Banners. Later, the land tenant system appeared. In 1830, the Yili General Yu Lin 玉麟 (1766-1833) memorialised to set up the land tenant system for the Manchu Banners; afterwards, the additional adult males in the Eight Banners were no longer engaged in cultivation, so a large area of land was rented out to civilians. ${ }^{45}$ 
A period of turmoil lasted more than a decade from 1864 in Xinjiang, and the soldiers of the Eight Banners garrisons and civilians of all nationalities suffered a great deal. In 1884, Xinjiang Province was established, and the Yili General Jin Shun 金順 (1831-86) gathered the remaining forces of the Eight Banners to restore the garrison system. At that time, there were only 2,000 soldiers, less than a third of the original number. ${ }^{46}$

At Yili, when the original Manchu garrisons were restored in 1884, land was given to the original Banners for cultivation, but not to the new Manchu garrisons. In 1895, General Chang Geng 長庚 (in office 1890-1901 and 1905-09) memorialised to reduce the number of soldiers and to increase their salaries in order to improve discipline. He ordered two Banners to cultivate the land and six Banners to be stationed at strategic locations. A Qitun was set up to the south of the Yili River, named Toqquz Tara (特古斯塔柳). Chang Geng managed to repair the irrigation channels and to build castles for the soldiers. In 1903, General Ma Liang 馬亮 (1845-1909) memorialised to add 240 soldiers to the new Manchu garrisons and to have them cultivate the land at Tegusitaliu with their families. ${ }^{47}$

The Qitun system at Tegusitaliu was different from the old one. Firstly, the old system did not require soldiers of the Eight Banners to cultivate land. At Tegusitaliu, on the contrary, soldiers of two Manchu Banners engaged directly in both cultivation and garrison duties. Secondly, the old system provided animals for cultivation only once. At Tegusitaliu, seed, animals, and agricultural implements were all officially provided each year. Thirdly, the old system let the Eight Banners manage their own land, while at Toqquz Tara, Qitun imitated Bingtun in giving a certain share of land to each soldier but cultivating it collectively; the harvest was all collected officially and a system of regulation of reward and punishment was adopted. At the end of 1903, General Ma Liang memorialised that 37,700 shi of unhusked grain had been collected since 1896, which he suggested be distributed to soldiers when the harvest was poor. In 1904, General Guang Fu 廣福 (in office 1904-06 and 1909-11) proposed to convert official land to private land and to distribute it to soldiers according to the size of their families. The soldiers were expected to provide their own seed and animals and to pay tax, the quota being based on the first year's harvest. This practice might have been helpful for frontier stability, but as the Qing Dynasty collapsed soon after, the Qitun at Yili was also brought to an end. ${ }^{48}$

46 Wang, Qingdai xibei tuntian yanjiu, 95-6.

47 Wang, Qingdai xibei tuntian yanjiu, 97.

48 For details, see Wang, Qingdai xibei tuntian yanjiu, 97-9. 
In 1917, Xie Bin went to Xinjiang to investigate the taxation system. He stayed overnight at Tegusitaliu and recorded that there were more than 200 households of the new Manchu garrison residing at Xiaoyingpan (小營盤) and more than 100 households inside Dayingpan (大營盤) city. Around the city there were more than 30 households cultivating the land. These people were all Manchus. ${ }^{49}$ This revealed that even though Qitun had been suspended, the Manchus were still cultivating the land as before.

In addition to the Manchu Eight Banners, in 1764-65, officers and soldiers were also transferred from Chahar, Xibo, Solun, and Ulet garrisons to cultivate the land at Yili. Table 5 shows the distribution and the water sources of these colonists' lands.

Table 5: The distribution and water sources of the colonists' land of four garrisons.

\begin{tabular}{|c|c|c|}
\hline Garrison & Location of the Land & Water Source \\
\hline $\begin{array}{l}\text { Xibo Garrison: } 8 \text { colonies } \\
\text { 1. The Bordered Yellow } \\
\text { 2. The Plain White Banners } \\
\text { 3. The Plain Red Banner } \\
\text { 4. The Bordered white Banner } \\
\text { 5. The Plain Yellow Banner } \\
\text { 6. The Bordered Red Banner } \\
\text { 7. The Plain Blue Banner } \\
\text { 8. The Bordered Blue Banner }\end{array}$ & $\begin{array}{l}\text { 1. Hejiger (豁吉格爾) } \\
\text { 2. Hejiger } \\
\text { 3. Batumengke (巴圖蒙柯) } \\
\text { 4. Zhohelo (鋽豁囉) } \\
\text { 5. Tashibulake (塔什布拉克) } \\
\text { 6. Ergemutolohai (額爾格穆托羅海) } \\
\text { 7. East of Zhohelo } \\
\text { 8. West of Zhohelo }\end{array}$ & $\begin{array}{l}1 \text { and } 2 \text { : spring water } \\
3 \text { to } 8 \text { : river water }\end{array}$ \\
\hline $\begin{array}{l}\text { Solun Garrison: } 2 \text { wings } \\
\text { 1. The Left Wing } \\
\text { 2. The Right Wing }\end{array}$ & & $\begin{array}{l}\text { 1: the West Alimatu } \\
\text { River (西阿里瑪圖河) } \\
\text { 2: Turgen River (圖爾 } \\
\text { 根河) }\end{array}$ \\
\hline Chahar Garrisons: 2 wings & $\begin{array}{l}\text { Lands were all located along the bank of } \\
\text { the Yibolola River (依博羅拉河). }\end{array}$ & $\begin{array}{l}\text { The land to the north } \\
\text { of the river used the } \\
\text { mountain springs while } \\
\text { the land to the south } \\
\text { conducted the river } \\
\text { water for irrigation. }\end{array}$ \\
\hline $\begin{array}{l}\text { Ulet Garrisons: } \\
\text { 1. The Upper Three Banners: } \\
\text { at } 4 \text { places } \\
\text { 2. The Lower Five Banners: } \\
\text { at } 16 \text { places }\end{array}$ & $\begin{array}{l}\text { 1. Dundachawusu (敦達察鳥蘇), } \\
\text { Huoyituchahanwusu (霍依圖察罕鳥蘇), } \\
\text { Termotu (特爾莫圖), Tamuha (塔木哈). } \\
\text { 2. Changman (昌曼), Hashi (哈什), } \\
\text { Chunjibulake (春稽布拉克), Subutai } \\
\text { (蘇布台), Hundolai (渾多賴), Gunzuoteha } \\
\text { (衰佐特哈), Kurkulei (庫爾庫壘), Nileha } \\
\text { (呢勒哈), Dajiergelang (大吉爾噶朗), } \\
\text { Suanzhutu (算珠圖), Teleke (特勒克), } \\
\text { Mingbulake (明布拉克), Tegusutaliu (特 } \\
\text { 古斯塔柳), Shalaboguoqin (沙喇博果沁), } \\
\text { Bahalake (巴哈拉克), Nuchugun (驽楚衰) }\end{array}$ & $\begin{array}{l}\text { They all used the water } \\
\text { available locally. }\end{array}$ \\
\hline
\end{tabular}

Source: This table was prepared by the authors based on Wang, Qingdai xibei tuntian yanjiu, 99-104.

49 Xie Bin 謝涁, Xinjiang youji 新疆游記 [Travels in Xinjiang], comp. Yang Lian 楊鎌 and Zhang Yiqing 張頤青 (Urumqi: The Xinjiang People's Press, 2001), 90. 
Of these four garrisons, Ulet and Chahar were mainly nomadic and only engaged partly in agriculture, but Xibe and Solun were mainly engaged in agriculture. The most effective colonised lands were those managed by the Xibo garrison. In 1903, among the officers and soldiers selected to manage the lands at Tegusitaliu, quite a large number were from the Xibo garrison. ${ }^{50}$

During the period 1821-50, the colonists' land at Yili made great progress. In 1839, General Yi Shan 奕山 (1790-1878) memorialised that there were 1,000 Uyghur households settled at Tashitubi (塔什圖畢) and 500 households at Sandaowan (三道灣), together cultivating 164,881 mou of land. In 1840, Buyantai 布彥泰 was assigned to the Yili general and under his management the hydraulic works and land cultivation entered a new stage. According to Buyantai's reports, the cultivated acreage in 1842 was as follows: Sankeshu (三棵樹) 25,350 mou, Hongliuwan (紅柳灣) and its surrounding area 8,000 mou, and Alepusi (阿勒卜斯) 161,000 mou. Moreover, after 1844, 100,300 mou were obtained at Aqiwusu (阿瓶烏蘇). The above figures made up a total of about 460,000 mou of land. ${ }^{51}$

As for the Huitun system at Yili, it was initiated in 1756 when General Zhao Hui 兆惠 (1708-64) led the army into the region and observed that there were only about 30 Uyghur. For supplying grain to the army, the Qing Government decided to transfer some soldiers of the Green Standard Army and the Uyghur from southern Xinjiang to cultivate the land at Yili. The first group of 300 Uyghur who went to Yili were from Aksu, Wushi, and Cailimu (賽哩木). In 1760, they carried animals, agricultural tools, seed, and grain to Yili under the guard of 500 officers and soldiers led by Deputy General Yi Zhu 伊柱. They climbed over the mountain of Musurdaban (穆蘇爾達坂) and marched for a fortnight to arrive at Yili. They settled at Hainukean (海努克安), a site to the south of the Yili River originally cultivated by Uyghur. They immediately built villages, repaired ditches, and started to plant seeds. Afterwards, they moved their families to Yili. The planting time in 1760 was somewhat late, but there were still some harvests in the autumn. In early 1761, the second group of Uyghur, comprising 500 households, arrived at Yili. In the sixth month of the same year, another 200 households arrived to help in harvesting. The number of Uyghur households reached 1,000 in 1761, as had been expected by the Governor-General Yang Ying-ju. Owing to the extensive land and abundant water resources, the Huitun were a remarkable achievement. As a result, the Qing Government ordered Uyghur to move continuously to Yili. By 1768, there were 6,388 Uyghur households there, so the Qing Government decided to stop the migration. ${ }^{52}$

50 Wang, Qingdai xibei tuntian yanjiu, 99-104.

51 Zhao Zhen, Qingdai xibei shengtai bianqian yanjiu, 140; Wang, Qingdai xibei tuntian yanjiu, 185-6, does not provide the acreage of land at each place.

52 Wang, Qingdai xibei tuntian yanjiu, 208-9. 
In 1773, the Yili General Yiletu 伊勒圖 (d. 1792) memorialised to divide the Uyghur households at Yili into nine colonies. There were seven colonies using the mountain spring: Hainuke (海努克, 600 households), Jirgelang (濟爾噶朗, 900), Tashuesitan (塔舒鄂斯坦，400), Eluositan (鄂羅斯坦，600), Bartuhai (巴爾圖海, 600), Huonohai (霍諾海, 800), Dardamutu (達爾達木圖, 500); and two colonies using the river water: Hashi (哈什, 500) and Boluoburgesu (博羅 布爾噶素, 1,100). ${ }^{53}$

The acreage of Huitun was estimated by measuring the quantity of seed planted. This practice was popular in Gansu and Hexi as well as southern and northern Xinjiang. The regulation required each household to plant 1 shi of wheat and barley as well as 0.5 shi of millet. This quantity of seed required 30 mou of land. Thus, it could be estimated that the total land area cultivated by Huitun at Yili was about 180,000 mou. $^{54}$

In July 1871, the Russian army occupied Yili, starting a colonial period that lasted 10 years. In 1881, under the Treaty of Yili China ceded to Russia more than $70,000 \mathrm{~km}^{2}$ of land, including Huitun at Dardamutu. Moreover, more than 100,000 residents of Yili were forced to move to Russia. With this lost, after being developed for more than 100 years, the Huitun at Yili disappeared forever. ${ }^{55}$

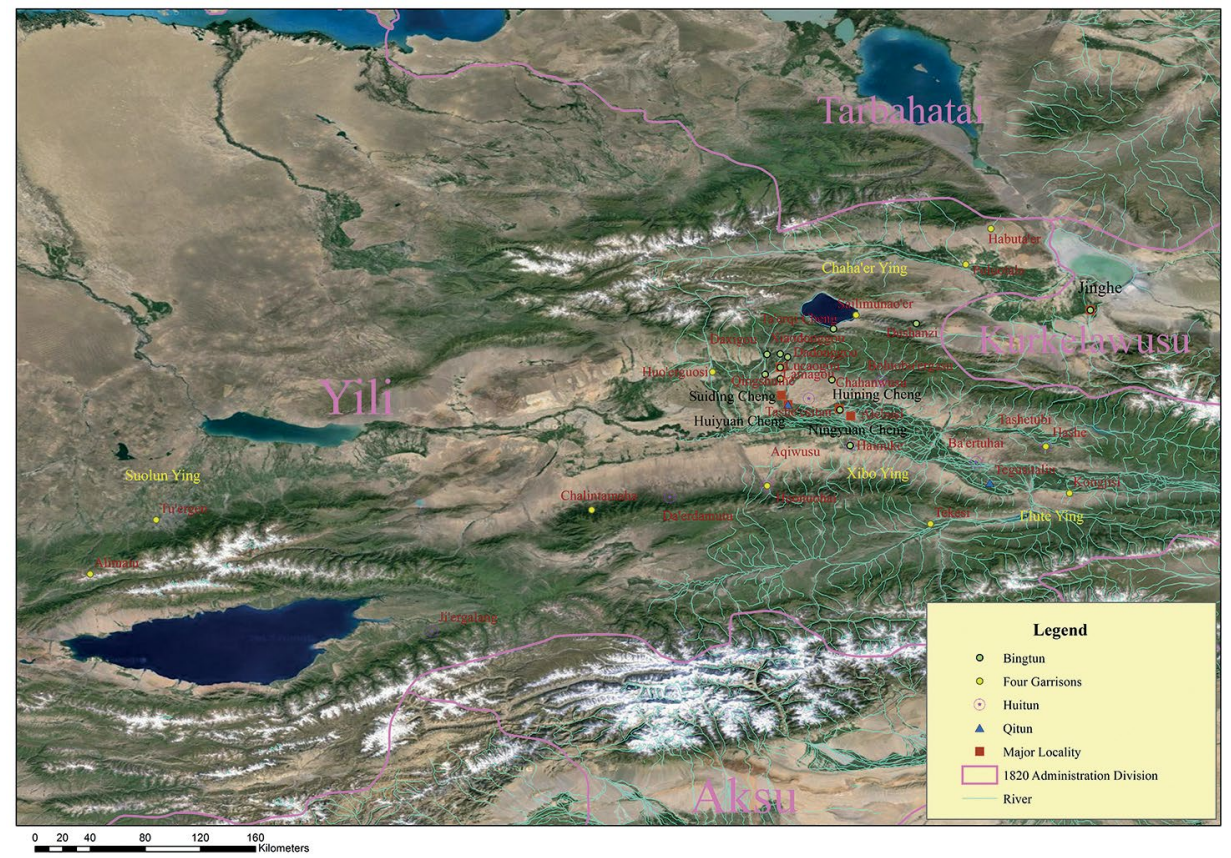

Map 10: The distribution of Tuntian at Yili.

53 Wang, Qingdai xibei tuntian yanjiu, 211. The data were taken from Knowledge about Xinjiang compiled by Imperial Order (欽定新疆識略). 


\subsection{Bingtun at Wushi and Aksu (see Map 11)}

In 1765, Bingtun at Wushi started with 20,000 mou of land. In 1777, 8,000 mou of land and 400 soldiers were distributed at Baoxingkong (寶興工), Chongyukong (充裕工), and Fengyingkong (豐盈工). There were also 70 soldiers at Toukong (頭工), 101 at Erkong (二工), and 130 at Sankong (三工). ${ }^{56}$ In 1762, Bingtun at Aksu had 150 mou of paddy fields with 15 soldiers. ${ }^{57}$

\subsection{Mintun at Kashgar and Yarkent (see Map 11)}

In 1831, the Yili General Chang Ling proposed to establish Mintun at Kelaheyi on land originally cultivated by the Uyghur. After the turmoil caused by Jahangir Khoja, the Uyghur fled and scattered, and Kelaheyi was taken to establish Mintun. After the Uyghur returned, Chang Ling assigned some lands of the rebellious officials to them; the Mintun at Kelaheyi was also known as 'exchanged land (Huanhuidi換回地)'. In 1832, according to a report by Chang Ling, there was more than 200 mou of land, and more than 500 cultivators were recruited. In 1835, the leading official of Kashgar, Xi-lang-a 西朗阿, reported of the situation of Mintun that there were 22,062 mou of 'exchanged land' and 506 recruited households; 1834 was the year for collecting tax, a quota of 607 shi of wheat being collected and stored in the granary. This report revealed that each colonist household was given 40 mou of land. Tax began to be paid after the land had been cultivated for three years, and each mou of land paid 0.03 shi of wheat. As for the origin of the colonists at Kelaheyi, they were mostly merchants according to some records. ${ }^{58}$

Barchuke was originally a wilderness in the jurisdiction of Yarkent. In 1822, the Yarkent managerial official Bi Chang 璧昌 led a group of 1,000 soldiers to open the land, build the city, dig the irrigation channels, and recruit cultivators; he spent a total of 10,000 tales of silver on these tasks. Up to 1824, the total cultivated land exceeded 24,000 mou, and 360 households had been recruited. The Mintun at Barchuke was similar to that at Kelaheyi: both had the practice of collecting tax after three years with the quota set at 0.03 shi of wheat for each mou of land. The colonists' land at Barchuke used the water from Daheguihunshui (大河拐渾水), which wound for about 800 li. Such a long channel was rather rare in the colonised lands of north-west China. The success of hydraulic works helped to expand the area of cultivated land. In 1836, Barchuke already had more than 100,000 mou of land. However, the corresponding number of cultivators was not recruited. Thus, the Qing Government agreed to let the Yili general enable the dismissed officials at Yili and Urumqi to contribute by recruiting

56 Wang, Qingdai xibei tuntian yanjiu, 51, 57.

57 Wang, Qingdai xibei tuntian yanjiu, 51.

58 Wang, Qingdai xibei tuntian yanjiu, 183-4. 
people to cultivate the land. The official would be rewarded if 100 households were recruited. But in more than 10 years, only one official was able to obtain this reward. ${ }^{59}$

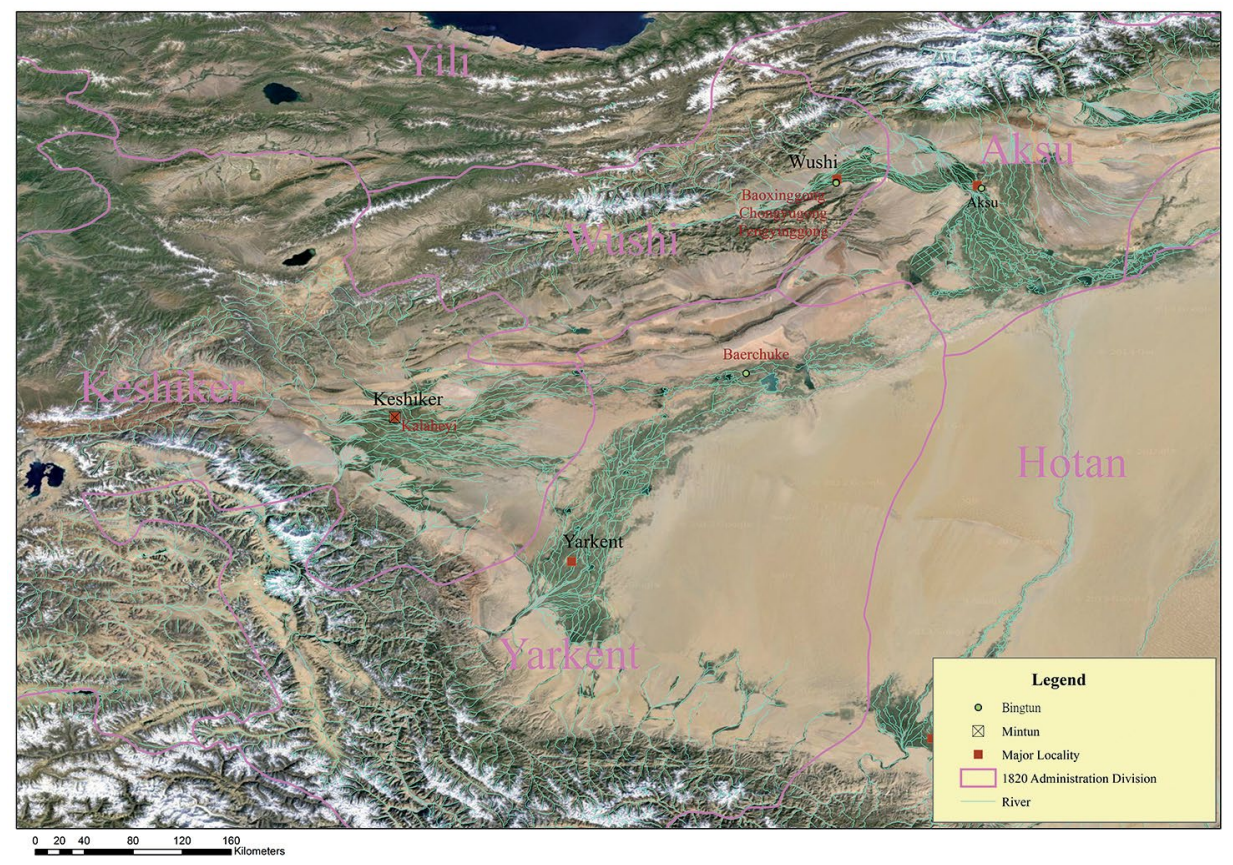

Map 11: The distribution of Tuntian at Wushi, Aksu, Kashgar, and Yarkent.

\section{The Tuntian System viewed from the Perspective of Property Rights}

When economists discuss the issue of property rights, they mostly contend that resources can be utilised more efficiently when a property right is defined clearly. For instance, Harold Demsetz emphasises that it is possible to utilise resources more efficiently when public land is converted to private land. Barry Field points out that when public landowners reach an agreement and transaction costs increase faster than exclusion costs, privatising that resource is more efficient; in the opposite circumstances, the public land system will be more efficient. ${ }^{60}$

59 Wang, Qingdai xibei tuntian yanjiu, 184-6.

60 See Harold Demsetz, 'Toward a theory of Property Rights', American Economic Review 52, no. 2 (1967): 347-59; Barry C. Field, 'The Evolution of Property Rights', Kyklos 42, no. 3 (1989): 319-45. 
From the viewpoint of property rights, it is possible to see that no matter whether it was Bingtun, Qitun, Qiantun, Mintun, or Huitun, the public land system prevailed in the beginning, but during the process of development, there was a tendency to convert to private land.

In Xinjiang, each soldier of the Green Standard Army in Bingtun was given a share of $20 \mathrm{mou}$ of land (though some had $21 \mathrm{mou}, 22 \mathrm{mou}$, or $22.5 \mathrm{mou}$ ). In addition to the land, farm animals, agricultural implements, and seed were all provided officially according to a certain quota. The variety of seeds included wheat, barley, highland barley, millet, broom-corn millet, rice, and sesame. Each colonist soldier was given 1.1 shi of seeds of various kinds. ${ }^{61}$ In other words, the colonist soldiers only had the right to use production factors, not property rights.

The rent system of Bingtun was one that came with a certain quota of labour service. Each soldier had to pay a certain amount of the harvest from his share of the land to the official granary, but his livelihood and that of his family were supported by the officially provided salary. Under this system, there was no direct relation between the rent and the salary. To keep soldiers working hard in cultivation, besides military control, there was a practice of reward and punishment; however, since the tax payment quota was relatively high, the chance of being rewarded was relatively low. ${ }^{62}$

At Yili, the Qitun system started to transform soon after its establishment in 1802. First, the public land of the Eight Banners was transformed to land managed by each Banner. In 1812, the Yili General Jin Chang investigated the Qitun situation and found that there were 24,000 mou of land already equally divided among the Eight Banners, and there was 40,000 mou of undivided land that was cultivated by additional soldiers of the Eight Banners. He discovered that, for many years, the undivided land could not provide the same level of surplus as the divided land. One reason was that the undivided land was located higher than the divided land and thus did not have adequate irrigation. The other reason was that the divided land was considered private, and this affected the harvest. With the planning of Jin Chang, more than 20,000 mou of irrigated land was obtained and divided into eight portions to add to the share of divided land cultivated by the Eight Banners. Moreover, the land tenant system appeared. Originally, it was forbidden to rent or sell Qitun land. In 1814, Song Yun even tried to stop the private practice of land renting. However, in 1830, the Yili General Yu Lin memorialised to let the two Manchu garrisons rent out the land. From then on, large areas of Qitun land was rented out to civilians. ${ }^{63}$

61 Wang, Qingdai xibei tuntian yanjiu, 65-72.

62 Wang, Qingdai xibei tuntian yanjiu, 72-6.

63 Wang, Qingdai xibei tuntian yanjiu, 93-5. 
The Qitun system at Yili was re-established in 1903, but basically adopted the Bingtun practice of the Green Standard Army. In 1904, General Guang Fu memorialised to have the Qitun land privatised by dividing it equally among the soldiers according to the size of their households; they no longer received money for repairing agricultural implements, and had to provide their own seed and farm animals, and pay a certain quota of the annual harvest. In 1911, Guang Fu memorialised again to have the land for the training army divided and given to the new Manchu Banners for cultivation, but this proposal was not put into practice as the Qing Dynasty collapsed soon afterwards ${ }^{64}$ Overall, Qiantun was carried out basically following Bingtun practice. In the late Qing period, Qiantun was converted to Mintun, as discussed above.

As for Mintun, in the beginning the land, agricultural implements, and seed were all officially provided and the farm animals were rented. Each household was given a quota of 30 mou of land, but in general, colonists could increase their landholdings by their own means. Tax began to be paid after the land had been cultivated for six years. In the late Qing, the conditions applying to officially provided land began to change: each two-person household was given 60 mou of high-grade land, 6 taels of silver for agricultural implements, 8 taels for repairing the house, 24 taels for two head of cattle, three shi of seed, 90 catties of noodles, and 1.8 tael for salt and vegetables. From the tilling in spring to the harvest in autumn, eight months was allowed for, and the price of seed was calculated at the current market price; thus the above items would need more than 73 taels of silver, which could be borrowed from the government - half to be repaid at the beginning of the year and the remainder the following year. Compared with the old practice, the burden of the colonist's household became heavier. But the period of tax payment was reduced from six to three years. ${ }^{65}$ The payment of tax meant that the colonists became self-employed farmers, but in northern Xinjiang, the movement of colonist households was still strictly controlled, meaning they were not able to freely leave their place of residence. ${ }^{66}$

At Yili, Huitun adopted a rent quota practice proposed by the managerial official A Gui 阿桂 (1717-97) in 1761: except for 1.5 shi of seed to be reserved by each person, the payment of tax was set at 16 shi, including 8 shi of wheat and highland barley and 8 shi of millet and broom-corn millet. If there was a poor harvest of wheat, highland barley, millet, or broom-corn millet, other kinds of grain could be paid as tax instead. In a good harvest year, a colonist household that planted 1.5 shi of seed could harvest $40 \mathrm{shi}$; the quota of tax was 16 shi, but after counting losses in measurement and to predation by hamsters, the

64 Wang, Qingdai xibei tuntian yanjiu, 98-9.

65 Wang, Qingdai xibei tuntian yanjiu, 179-80, 192.

66 Wang, Qingdai xibei tuntian yanjiu, 181-2. 
actual tax payment was $17.2 \mathrm{shi}$, which was 43 per cent of the harvest. When the harvest was poor, the rate of tax was even higher. Compared with the ratio of 4:6 at Caibashihu (Hami), the rent of Huitun at Yili was somewhat higher. ${ }^{67}$

In short, the colonization of land in Xinjiang during the Qing Dynasty was started with resources provided by the government; however, there was a tendency of converting public land to private land, and after Mintun had paid the tax, the land formally became privately owned.

\section{The landscape shaped by the Tuntian}

Before going on to discuss the landscape shaped by the Tuntian system, it is notable that James A. Millward has provided ample evidence of Xinjiang's environmental history based on studies of land, climate, mountains, and water, as well as colonial efforts. ${ }^{68}$

As discussed in Section 1, the land area of Bingtun was usually quite large, except at Aksu where the acreage of paddy fields was very small. In 1768-71, Ji Yun observed at Urumqi that the fields were cultivated alternately to allow soil fertility to recover, and farmers did not fertilise the land. He also noted the practice of crude sowing by hand without regular distribution in each furrow. ${ }^{69}$ About 1780, when the pasture of Ulet at Yili was opened up for cultivation, the land was left to lie fallow for two to three years after having been planted for one year. Later, the Yili General Yi- le-tu 伊勒圖 suggested that the fallow cycle should be extended to seven years. In 1804, the Commander Na-er-song 納爾松 suggested that the cycle should be cut to five years. ${ }^{70}$ In 1917, Xie Bin observed at Tegustaliu that the fallow cycle was six years for the land of new Manchu garrisons. ${ }^{71}$ From the viewpoint of the evolution of land utilisation, at places where the population was relatively low compared to the area of available land, the land fallow system tended to prevail. ${ }^{72}$ In Xinjiang, the short fallow system

\footnotetext{
67 Wang, Qingdai xibei tuntian yanjiu, 216.

68 James A. Millward, 'Towards a Xinjiang Environmental History: Evidence from Space, the Ground, and in Between', in Studies on Xinjiang Historical Sources in the 17-20th Centuries, ed. James A. Millward, Shinmen Yasushi, and Sugawara Jun (Tokyo: The Toyo Bunko, 2010), 279-303.

$69 \mathrm{Ji}$, Urumqi tsashi, 171.

70 Zhao Zhen, Qingdai xibei shengtai bianqian yanjiu, 182-83.

71 Xie, Xinjiang youji, 90.

72 Ester Boserup, 'Environment, Population, and Technology in Primitive Societies', in The Ends of the Earth: Perspectives on Modern Environmental History, ed. Donald Worster (Cambridge: Cambridge University Press, 1988), 27-8.
} 
was adopted after the 1850s and this revealed that the population conditions were not yet ready for adopting the refined land cultivation system adopted for paddy fields in eastern China. ${ }^{73}$

In the early stage of the cultivation of colonised land, the harvest was abundant. For instance, Ji Yun wrote a poem about the landscape around Urumqi saying that in autumn, there were continuous furrows of spring wheat and the green scene extended to Jingho for a thousand miles. ${ }^{74}$ Moreover, in 1770, the ShaanGan Governor-General Ming Shan 明山 (in office 1769-71), who was entrusted with investigating the colonists' land around Jimusa after being absent from Xinjiang for 13 years, memorialised:

When I proceed along the route, I observe that not only the wilderness of bush has been turned into abundant products, [but also] the population in the city is rather dense and merchants gather to do business, [and] the scene of neighborhood is all new and it cannot be compared with the old days. ${ }^{75}$

In order to obtain harvests from the colonised land, the most important factor was to have irrigation water in addition to the input of labour. According to Huang Shengzhang, in the Qing Dynasty, the irrigation works in Xinjiang were first centred at Yili and extended from a northern to a southern route; in the later stage, it was centred at Hami and developed from east to west. In Xinjiang, there were five irrigation methods: (1) building a large channel, (2) diverting river flow, (3) using a water trough (槽引水法), (4) digging wells, and (5) using snow water and other water resources. Of these methods, that of conducting water in a water trough was quite special to Xinjiang. This method was first developed in the Chang-an (長安, today's Xi-an) area in Shaanxi and then transferred to many other places. In the beginning, it was used to conduct water for city supply and, later, for farming. This method appeared in Xinjiang in the early Qing period, and extended more than 100 li between Jianshanzi 尖山子 and Kuisu 奎蘇, with water conducted from the southern mountain in nine main channels. Moreover, this method was also used around Yili. For instance, in the colonised lands north-west of Huiyuan city and south-west and northwest of Yikeshu (一顆樹), the water trough was constructed to conduct the spring water from the north of Talechi (塔勒奇) city for irrigation. The natural conditions in Xinjiang made this method suitable for adoption in many places. It was very useful for preventing leakage, saving water, and irrigating more land.

73 Li Bozhong李伯重, ‘Tian, di, ren de bianhua yu Ming Qing Jiangnan shuidao shengchan 天、地、人的 變化與明清江南水稻生產' [Changes in Heaven, Earth, and Man and Rice Production in Jiangnan], Zhongguo Jingjishi Yanjiu 中國經濟史研究 [Studies on Chinese Economic History] 4 (1999): 103-21.

$74 \mathrm{Ji}$, Urumqi tsashi, 165.

75 China's First Archives 中國第一檔案館, ‘Qianlong nianjan ximin tunken Xinjiang shiliao 乾隆年間徙民 屯墾新疆史料' [Historical source materials on moving the people to cultivate land in Xinjiang], Lishi Dangan 歷史檔案 [Historical Archives] 3 (2002): 20. 
But the usage of this method rose and fell. In 1886, the Dihua Sub-Prefect Pan Xiaosu 潘效蘇 (b. 1838) changed to the use of wooden troughs (mujian 木梘) for conducting the water step by step in order to make it flow smoothly. This experiment was not only successful but was also considered at that time the most effective method of conveying water.

In addition, Xinjiang had abundant sources of snow water, which provided conditions conducive to irrigation. Large-scale utilisation of snow water began only after the 1750s and the establishment of the colonised lands at Yili and other places. During the period 1796-1820, the water source for the colonised land was only once seriously affected due to the shortage of snow water. The snow water was utilised at Yili in addition to the water conducted from the Yili River. At Hami, the snow water was also used for irrigating the colonised land.

The hydraulic works in Xinjiang during the Qing period were larger in scale and the technology more complicated than in earlier periods. Similar to the practice in the Han Dynasty (206 BC - AD 200), the introduction of a large-scale irrigation system into Xinjiang was managed by experienced officials from the interior. For instance, during the first half of the nineteenth century, the big channels built at Yili were all managed by the Yili General using methods developed in the interior. At Yili, in 1802-16 when Song Yun built hydraulic works such as Tonghuiqü (通惠渠), irrigation driven by waterwheel was introduced into Xinjiang.

The use of groundwater with karez (Kanrjing 坎兒井) introduced from Central Asia was a speciality of Xinjiang. The Chinese term 'Kanrjing' is a translation of 'karez', meaning an underground waterway. The karez in Xinjiang was mainly constructed in the Turfan area, where the earliest record of its use is in 1820 at Yarhu (雅爾湖, i.e. Yarkhoto 雅爾和屯), 20 li to the west of Turfan, for the irrigation of $252 \mathrm{mou}$ of land. Up to the 1821-50 period, the karez was used only at Turfan. In 1844-45, when Lin Zexu assisted Quan Qing in building hydraulic works in Xinjiang, they finally decided to conduct the water from Yilalike (伊拉里克) River in a main channel with branches above ground instead of using a karez. After Lin Zexu was recalled to Beijing in winter 1845, Sa Yinga 薩迎阿 (d. 1857) became the Yili General, and he completed Lin Zexu's plan of building more than 60 karez. This was the first large-scale project of karez construction outside Turfan, though it was still within the Turfan Basin.

The second large-scale development of karez was in 1880 after Zuo Zongtang 左宗棠 (1812-85) suppressed the rebellion of Muhammad Yaqub Bek (Agubo 阿古柏, 1820-77). According to a memorial submitted by Zuo in 1880, $185 \mathrm{karez}$ 
had been constructed at Turfan. ${ }^{76}$ As for the karez in places outside Turfan, they were mostly constructed in the early twentieth century with techniques transferred from Turfan.

The oases in Xinjiang are mostly located on plains at the foot of mountains or in rings around the desert. When rivers flow to plains at the foot of the mountains, they disappear underground. For solving this problem and saving water resources, three methods were applied in Xinjiang: (1) paving fells at the bottom of the channel (lining it with woollen blankets), put into practice at Hami, Turfan and Urumqi; (2) using grass or sandstone at the bottom of channels; (3) constructing a torrent dam (laoba 澇壩), first found in the Qianlong period and widely adopted in Xinjiang. The torrent dam was used to store water, to conduct storm water, or to extract water from channels and rivers for use in times of water shortage. The Uyghur called this kind of dam 'Bositang' (伯斯塘). The laoba in Xinjiang was developed first for the storage of water as an element in the irrigation system, but only later did it become an important component of the irrigation system. ${ }^{77}$

In addition to the landscape created by irrigation and farming activity, there were also other landscapes shaped by humans. In Bingtun districts, walled villages were usually built to accommodate soldiers, surrounded by land for them to till. ${ }^{78}$ During the period $1762-71$, the walled villages built around Dihua included Huilaibao (惠徠堡, i.e. Liudaowan 六道灣), Lufengbao (霋豐堡, i.e. Qidaowan 七道灣), Xüanrenbao (宣仁堡, i.e. Tougong 頭工), Huaiyibao (懷義 堡,i.e. Ergong二工), Lequanbao (樂全堡, i.e. Sangong 三工), Baochangbao (寶昌堡, i.e. Sigong 四工), Yuchangbao (育昌堡, old name Shuangchahe 隻倠 河), Shihebao (時和堡, old name Liushugou 柳樹溝). The length of the village walls was usually $1.7 \mathrm{li}(0.85 \mathrm{~km} ; 1.55 \mathrm{li}$ or $0.775 \mathrm{~km}$ for the latter two villages), and their height about 1.1 or 1.2 zhang ( 3.3 or 3.6 metres), and each village had three gates and 300 rooms for soldiers. Moreover, the walled villages of Suilaibao (綏來堡, i.e. Manas瑪納斯), Suichengbao (逐成堡, i.e. Kerkelawusu

76 See Kim Hodong, 'Eastern Turki Royal Decrees of the 17th Century in the Jarring Collection', in Studies on Xinjiang Historical Sources in 18-20th Centuries, ed. Millward, Yasushi, and Jun, 73, for a discussion of ownership of karez in the Mongol period. Also see Éric Trombert, 'The Karez Concept in Ancient Chinese Sources: Myth or Reality?' T'oung Pao 94, no. 1-2 (2008): 115-50, for an examination of the historical process of the development of the karez technique in China.

77 Zuo Zongtang 左宗棠, ‘Banli Xinjiang shanhou shiyi ze 辦理新疆善後事宜摺’ [A memorial regarding measures taken in Xinjiang after pacifying the rebellion], in Zuo Wenxianggong quanji 左文襄公全集 [Complete collection of the works of Zou Zongtang] (Taipei: Wenhai Publishing Co., 1964), 2254. For a study of developing karez by Zuo Zongtang, see Peter Lavelle, 'Cultivating Empire: Zuo Zongtang's Agriculture, Environment, and Resconstruction in the Late Qing', in China on the Margins, ed. Sherman Cochran and Paul G. Pickowicz (Ithaca, NY: Cornell University Press, 2010), 43-64, especially 53

78 For details of the above discussion on irrigation methods, see Huang Shengzhang 黃盛璋, 'Xinjiang shuili jishu de chuanbo he fazhan 新疆水利技術的傳播和發展' [The Transmission and Development of Hydraulic Technology in Xinjiang], Nongye Kaogu 農業考古 [Agricultural Archaeology] 1 (1984): 78-86; 2 (1984): 172-83. 
庫爾喀喇烏蘇), and Fengrunbao (豐潤堡, i.e. Jinghe 精河) were all built by soldiers themselves without official management; therefore, their length and height were not recorded. Inside the walled villages, in addition to houses for soldiers and their families, there were also storehouses for agricultural implements and weapons, granaries, offices, and residences for the managing officials. Most of these walled villages developed later into large villages or towns - some of them have even retained their old names to the present day. ${ }^{79}$

For providing cattle and horses for use by the colonists, from 1760 on the Qing Government established pastures at Yili, Urumqi, Balikun, and Tarbahatai. To provide agricultural implements, an iron foundry was set up in 1764 at Reshuiquan (熱水泉), to the north of Dihua city. ${ }^{80}$ These are also components of the landscape shaped by humans.

Stations such as Juntai (軍臺, military patrol station), Duntang (墩塘, beacon-mound, also known as Yingtang 營塘), Izhan (驛站, post-stage), and Kalun (卡倫, the Manchu word meaning a post) were set up along the roads for delivering official documents and materials, accommodating travelling officials, and investigating deserters. Juntai and Duntang, however, were not set up at all places. From Yili to Tarbahatai and Jinghe, there were Juntai but no Duntang. From Jinghe to Urumqi, there were both Juntai and Duntang. From Urumqi to Balikun and then to Hami, there was no Juntai but there were Duntang. From Turfan to Hami, from Keshiger to Turfan, and from Hami to Jiayuguan, there were Juntai but no Duntang. ${ }^{81}$ As for Izhan, they were set up only between Balikun and Dihua for delivering documents after the administrative divisions were changed to zhou (州) and xian (縣), because it was no longer possible to deliver documents through military patrol stations. ${ }^{82}$

Among these facilities, the one most directly related to the colonised land was Kalun, which specialised in investigating deserters. There were seven Kalun at Tarqi (塔爾奇), located to the north of Yili city and the ford of the Yili River; there were also seven at Yarkent city from the south-west to the north-east; five at Kuche city from the north-west to the south; two at Kelashar city from the north-east; six at Turfan city from the south-west to the east; and four in the north-east of Hami city. ${ }^{83}$ These stations and posts also formed a part of the landscape shaped by humans.

\footnotetext{
79 Wang, Qingdai xibei tuntian yanjiu, 56.

80 Anonymous, Urumqi zhenglüe, 68-70; Wang, Qingdai xibei tuntian yanjiu, 59-60.

81 For details, see Wang, Qingdai xibei tuntian yanjiu, 231-52.

82 Qi Yunshi 祁韻士, Xichui yaolüe 西陣要略 [A Brief History of the Western Frontier], in Zhongguo shaoshu minzu guji jicheng, ed. Xu 徐麗華, 76: 514.

83 Anonymous, Urumqi zhenglïe, 46.
} 


\section{Observations of Lin Zexu and Xie Bin}

This section will compare the observations of Lin Zexu in 1842 and Xie Bin in 1917 in order to understand changes in Xinjiang's landscapes from the midnineteenth to the early twentieth century.

After the defeat of the Qing Army in the Opium War, the Daoguang Emperor had Lin Zexu, the official in charge of dealing with opium, dismissed and sent to Yili on 28 June 1841. At that time, he was on a mission to close breaches of the Yellow River. Nevertheless, the Emperor ordered Lin to go to Xinjiang on 18 March 1842, and he went once the river work was compled.$^{84}$ Lin left Xi-an on 11 August 1842 and arrived at Yili on 10 December. His dairy of this trip was collected in Hege jicheng (荷戈紀程). In addition, Lin went to southern Xinjiang in 1844 to investigate the situation of land cultivation; part of his diary for this period was collected in Nanjiang kanken riji (南疆勘墾日記). ${ }^{85}$

Three quarters of a century later, Xie Bin was entrusted by the Ministry of Finance of the Peking Government (1912-28) to go to Xinjiang and Artai (阿爾泰) to investigate financial conditions. He left Peking on 6 December 1916 and arrived at Shuzhou on 5 February 1917. Then he departed from Shuzhou and arrived at Yili on 10 May. His observations en route were collected in Xinjiang youji (新疆游記). ${ }^{86}$

The journeys of Lin and Xie were divided into three sections: (1) from Shuzhou to Hami, (2) from Hami to Dihua, and (3) from Dihua to Yili. The routes followed by them from Hami to Dihua differed. There are three routes available from Hami to Urumqi: north, south, and middle (the small south route). Lin took the small south route. ${ }^{87}$ But Xie encountered strong winds during his journey and could not get off his chariot when passing by Dashitou (大石頭) along the middle route; therefore, he changed routes, going from Shanshan (鄯善) to Turfan and from there to Dihua. ${ }^{88}$ (See Map 12.) Moreover, in Lin's Nanjiang kanken riji, a section of the route from Dihua to Turfan was the same but was taken in the opposite direction. Below, the observations of Lin and Xie are compared at some selected points. ${ }^{89}$ The purpose of the account is to illustrate changing perceptions of the same places by placing the two records side by side.

\footnotetext{
84 Qi Yunshi, Xichui yaolüe, 513-14.

85 Qingshigao 淸史稿 [The Draft of Qing History], chüan 19: 683, 686; chüan 369: 11493.

86 Lin Zexu, Nanjiang kanken riji 南疆勘墾日記 [Diary of an Investigation into Land Cultivation in Southern Xinjiang], in Gan Xin youtsong huibian 甘新遊蹤彙編 [Collection of Travels in Gansu and Xinjiang], ed. Library of Central Ethnic College 中央民族學院圖書館 (1983).

87 Xie, Xinjiang youji, 1-14.

88 Lin Zexu, Hege jicheng, 556.

89 Xie, Xinjiang youji, 26.
} 


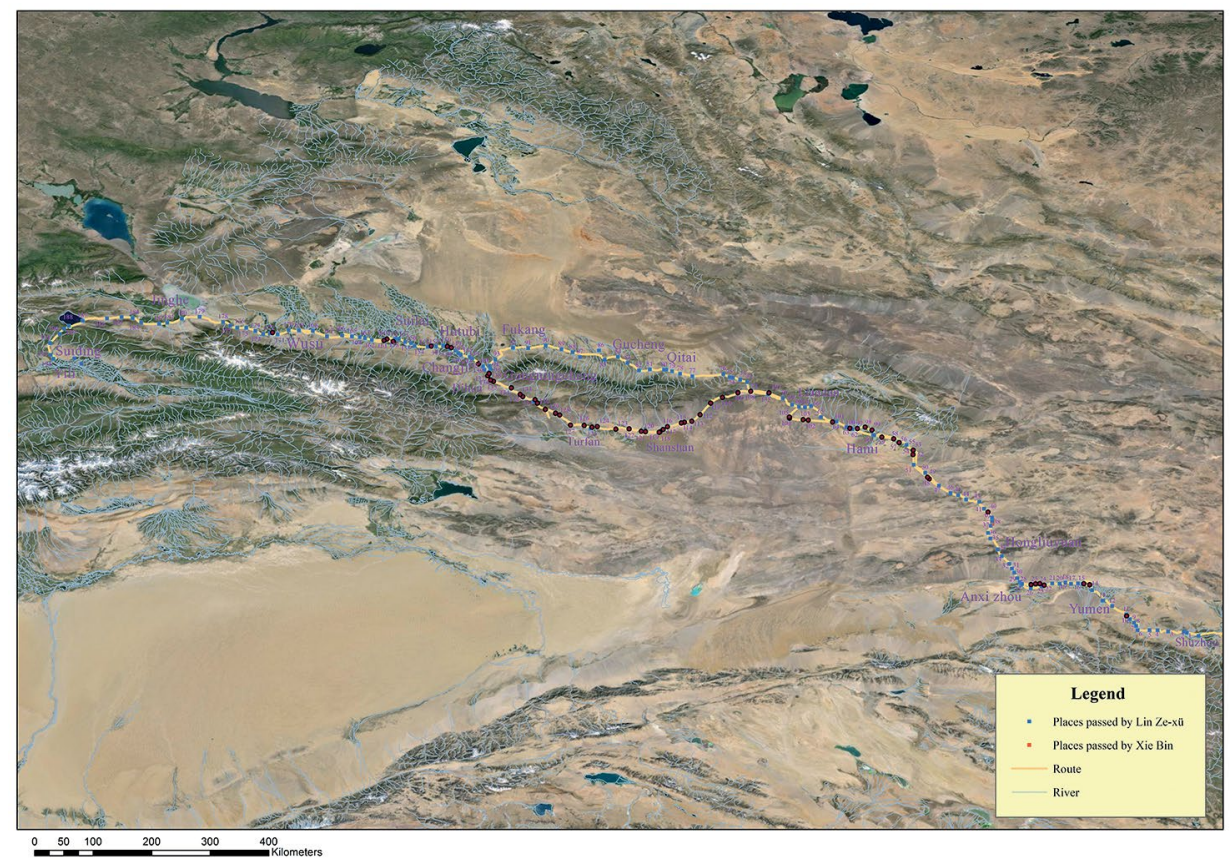

Map 12: The westward routes taken by Lin Zexu (1842) and Xie Bin (1917).

\subsection{The disappearance of red willow (Hongliu 紅柳, Tamarix ramosissima)}

There was a place named Hongliuyuan (紅柳園) 160 li to the north-west of Anxi zhou (安西州) of which Lin Zexu said: 'I am not sure how the local name was given. There is no[t] the so-called red willow, nor a single tree.' Xie Bin also noted: 'There is actually no willow tree.'

Forty-five li before arriving at Xingxingxia (星星峽), there was also a place named Hongliuhe (紅柳河). Lin said: 'This is no willow tree, too.' Fifty li after passing Xingxingxia, there was a place named Small Hongliuyuan, but Lin still did not see any red willow tree. He asked the natives and they replied: 'The trees were all cut down for firewood, thus the scene was so rough and clear.' But Xie saw a forest of red willows at Yangjiazhuang (楊家庄), located about 20 li to the east of Anxi zhou. Lin noticed that the three places with the name 'red willow' were all located to the west of Anxi zhou; it is difficult to conclude that the disappearance of red willow from this area was related to the development of colonised land, but it seemed possible. 


\subsection{Changes in the landscapes shaped by humans along the route}

Both Lin and Xie recorded much about the residents living in the walled villages along the road. Comparing the two accounts reveals changes possibly related to destruction caused by the Muslim rebellion of 1862-73: at Shajingzi (沙井子), 50 li to the north-west of Hongliuyuan, Lin observed that there were dozens of households, but Xie saw only three abandoned shops and no residents.

At Toubao (頭堡), 40 li toward Hami, Lin observed: “There was a walled city with more than 100 Uyghur households living inside the city and more than 20 Han households outside.' However, Xie recorded: 'The walled village was very small, there was only one post-stage and one temple. There were also three chariot shops, five Han households, 12 Uyghur households, and 18-19 households of Turbaned Moslems' (纏民).

At Sanbao(三堡), 60 li from Hami, Lin said there was a place named Longshengtian (隆盛店) where the population of the Han and Hui peoples was about the same as at Toubao. However, Xie found its wall was already ruined and there were 15 Han households, 12 Uyghur households and 22 Turbaned Muslim households.

At Hutubi (呼圖壁), more than 90 li from Changji xian (昌吉縣), Lin noted only that there was a walled city, but by Xie's time the wall was ruined and it was desolate inside the city; business took place only in the southern suburb. Before the Muslim rebellion, there had been more than 2,000 households under the jurisdiction of this city, but now there were little more than 600 .

At Sandaohe (三道河), 120 li from Suilai xian (綏來縣), Lin said that there were about 1,000 households, but Xie recorded only about 20 .

At Anjihai (安濟(集)海), 145 li from Suilai xian, Lin said there were 5,000 households; Xie said there were 40-50 residents' shops. At Kuidun (奎墩, i.e. Kuitun-I 奎屯驛), 90 li from Anjihai, Lin said there were more than 100 households, but Xie said there was only one chariot shop and three small shops.

At Ganhezi (乾河子), 30 li to the south-west of Wusu xian (烏蘇縣), Lin saw small shops at the side of the road; Xie saw only one broken shop.

On entering Sitai (四臺) at the border of Yili, Lin said the houses were very small and there were only a few of them and two rather humble inns; Xie said there was one dirty, rustic inn that provided a mere footing.

Lin found 600 Han soldiers stationed at Dalucaogou (大蘆草溝, i.e. Guangren city 廣仁城), about 90 li from Yili, and the inn inside the city was cleaner than the one along the road, but Xie said the city wall was mostly ruined and there were about 200 shops and residential houses in a suburb. 
Between Dihua and Turfan, Lin and Xie travelled in opposite directions, but their observations can still be compared. At Daban city (達坂城), about 185 li to the south-east of Dihua, Lin saw more than 100 households; Xie recorded about 60 households and shops, and around the neighbourhood there were more than 500 farming households, of which three quarters were Uyghur. At Sankequan (三個(角)泉), 100 li to the south of Daban, Lin said there were about 10 households; Xie saw no residents, and only two shops and one temple. At a place about 30 li before he reached Turfan, Lin saw karez and noted:

The cave well is called kajing (卡井) which can conduct the water to flow horizontally; from south to north, the water is conducted higher and higher, the water flows through the cave under the earth, it is indeed something inconceivable. At this place cotton is produced in a great amount which is the benefit of water brought forth by kajing. ${ }^{90}$

Xie did not mention karez here, though he did at Qiketengmu (七克騰木), located 90 li to the north-east of Shanshan (鄯善), at Sanshilidun (三十里墩), 60 li from Qiketengmu, and from Ergong (二工, 53 li to the west of Shanshan) to Subashi (蘇巴什, 42 li to the west of Ergong).

\subsection{Descriptions of natural resources and landscapes}

Both Lin and Xie mentioned the problem of drinking water. At Shaquan (沙泉, i.e. Shajingzi 沙井子), 90 li to the north-west of Xingxingxia, Lin found the water was salty. He bought 'a container of bottle-gourd to store water to come here'. Xie said the spring water at Shaquan was quite flourishing. Upon arriving at Kushui-I (苦水驛), 80 li to the north-west of Shaquan, Xie said the spring there had a depth of eight chi (尺, 2.4 metres), but the water was very bitter, so drinking water was brought from Shaquan. Further on at Geziyandun (格子煙墩), 140 li from Kushui-I, Lin said that the water was drinkable. Upon arriving at Changliushui (長流水), 70 li from Geziyandun, Xie noted that there was a spring on the north-west slope, and the water was abundant and clear, tasting very sweet and cool.

Both Lin and Xie paid much attention to trees along the road. At Huanglugang (黃蘆崗), 70 li to the south-east of Hami, Xie noticed that there were dozens of aspens (Baiyang白楊, Salicaceae). Upon arriving at Xinzhuangzi (新庄子), 30 li to the east of Hami, Xie described forests of willows (Yang 楊, Populus) and elms (Yu 榆, Ulmus pumila). At Hami, Lin saw much farm land with dense forests. At Santaixün (三臺汛), 70 li to the west of Jimusa (濟木薩), Lin saw numerous elm and willow trees. At Erbao (二堡) 60 li from Hami, Xie noticed that the trees in the village were shady; at Liushuquan (柳樹泉), 50 li from Erbao, Xie also

90 For detailed records of Lin and Xie, see Appendix in the Chinese version of this paper. 
noticed that trees lined the village roads. Between Chezhaluquan (車䇫轤泉), 275 li from Liushuquan, and Qijiaojing (七角井), 58 li from Chezhaluquan, Xie saw many poon trees (Hutong 胡桐, Calophyllum) with a height less than one zhang (c. 3 metres), having been cut down for several years, with only dry wood left on the ground. From Shanshan (i.e. Pizhan 辟展) to Ergong (二工), a distance of $53 \mathrm{li}$, Xie saw trees along both sides of the village road. From Turfan to Yarya (雅爾崖), 20 li from Turfan, Xie noted that along the road there were officially planted willows, and in the villages, springs and trees could be seen continuously. At Baojiadian (鮑家店), 15 li to the east of Suilai xian (綏來縣), Lin noticed that trees were quite numerous. From Wusu xian (烏蘇縣) to Ganhezi (乾河子), 30 li to the south-west of Wusu xian, Lin said there were no residents along the road, but there were numerous trees; Xie said that there were abundant red willow trees about. Between Heyanzi (河沿子, 130 li from Ganhezi), and Guertu (固爾圖, 30 li from Ganhezi), Lin said there was a section of level road with numerous trees. En route from Shaquan-I (沙泉驛) to Jinghe (精河), a distance of 60 li, Xie saw no tree along the road, and even small bushes such as camel thorn, red willow, or white vine were rarely seen. From Songshutou (松樹頭 190 li to the east of Yili) to Ertai (二臺 20 li to the west of Songshutou), Lin noted that there were thousands of pine trees (Song 松, Pinaceae) on the mountain slopes. Two shops at Ertai were built entirely with blocks of pine, which indicated that they were rather cheap. Xie said the Yili Wood Company had an examining station and a team to guard the roads, which revealed that this was a place for logging.

It should be noted that Wen Huanran has pointed out that there were great changes in the forest history of Xinjiang as a result of several natural and human factors. In general, these factors interacted and restrained each other, except that in the Qing Dynasty when the effect of wars was greater, human economic activity was usually the leading factor..$^{91}$ The collection of firewood, building of houses with pine blocks, and tree felling mentioned by Lin and Xie show that human economic activities had an effect on the forest in Xinjiang.

Besides the above observations, Lin and Xie also made statements relating to the natural landscapes of deserts, rivers, rapids, lakes, salt lakes, and mountain gorges. Xie's descriptions are especially detailed, which need not be repeated here.

91 Lin Zexu, Nanjiang kanken riji, 6-36. 


\section{Concluding Remark}

This paper has used GIS maps to illustrate the spatial and temporal distribution of the Tuntian system in Xinjiang. The viewpoint of property rights confirms a tendency for this system to change from public to private land. Moreover, this paper also discussed the landscape shaped by humans through the practice of the Tuntian system. Finally, a comparison of observations by Lin in 1842 and Xie in 1917 reveals that in the course of 75 years, some environmental changes in Xinjiang were related to the colonists' land cultivation and some to wars.

\section{Appendix: Conversion of measurements}

$1 \mathrm{mou}$ 㽞 $=666.5$ square metres

$1 \mathrm{li}$ 里 $=0.5$ kilometre

1 shi 石 $=120$ catties

$1 \mathrm{chi}$ 尺 $=0.303$ metre

1 zhang 丈 $=3.03$ metres 
This text is taken from International Review of Environmental History, Volume 2, 2016, edited by James Beattie, published 2016 by ANU Press, The Australian National University, Canberra, Australia. 